This PDF is a selection from a published volume from the National Bureau of Economic Research

Volume Title: NBER Macroeconomics Annual 2001, Volume 16

Volume Author/Editor: Ben S. Bernanke and Kenneth Rogoff, editors

Volume Publisher: MIT Press

Volume ISBN: 0-262-02520-5

Volume URL: http://www.nber.org/books/bern02-1

Conference Date: April 20-21, 2001

Publication Date: January 2002

Title: Do We Really Know that Oil Caused the Great Stagflation? A Monetary Alternative

Author: Robert B. Barsky, Lutz Kilian

URL: http://www.nber.org/chapters/c11065 
Robert B. Barsky and Lutz Kilian

UNIVERSITY OF MICHIGAN AND NBER; AND

UNIVERSITY OF MICHIGAN, EUROPEAN CENTRAL BANK, AND CEPR

\section{Do We Really Know that Oil Caused the Great Stagflation? A Monetary Alternative}

\section{Introduction}

There continues to be considerable interest, both among policymakers and in the popular press, in the origins of stagflation and the possibility of its recurrence. The traditional explanation of the stagflation of the 1970s found in intermediate textbooks is an adverse shift in the aggregate supply curve that lowers output and raises prices on impact. ${ }^{1}$ Indeed, it is hard to see in such a static framework how a shift in aggregate demand could have induced anything but a move of output and prices in the same direction. This fact has lent credence to the popular view that exogenous oil supply shocks in 1973-1974 and 1978-1979 were primarily responsible for the unique experience of the 1970s and early 1980s. For example, The Economist (November 27, 1999) writes:

Could the bad old days of inflation be about to return? Since OPEC agreed to supply-cuts in March, the price of crude oil has jumped to almost $\$ 26$ a barrel, up from less than $\$ 10$ last December and its highest since the Gulf war in

We have benefited from comments by numerous colleagues at Michigan and elsewhere. We especially thank Susanto Basu, Ben Bernanke, Olivier Blanchard, Alan Blinder, Mark Gertler, Jim Hamilton, Miles Kimball, Ken Rogoff, André Plourde, Matthew Shapiro, and Mark Watson. We acknowledge an intellectual debt to Larry Summers, who stimulated our interest in the endogeneity of oil prices. Allison Saulog provided able research assistance. Barsky acknowledges the generous financial support of the Sloan Foundation. The opinions expressed in this paper are those of the authors and do not necessarily reflect views of the European Central Bank.

1. For example, Abel and Bernanke (1998, p. 433) write that-after a sharp increase in the price of oil-"in the short run the economy experiences stagflation, with both a drop in output and a burst in inflation." 
1991. This near-tripling of oil prices evokes scary memories of the 1973 oil shock, when prices quadrupled, and 1979-80, when they also almost tripled. Both previous shocks resulted in double-digit inflation and global recession. . . . Even if the impact will be more modest this time than in the past, dear oil will still leave some mark. Inflation will be higher and output will be lower than they would be otherwise.

Academic economists, even those who may not fully agree with the prevailing view, have done little to qualify these accounts of stagflation. On the one hand, the recent scholarly literature has focused on the relationship between energy prices and economic activity without explicitly addressing stagflation (see, e.g., Hamilton, 1983, 1985, 1988, 1999; Rotemberg and Woodford, 1996). On the other hand, some authors (e.g., Bohi, 1989; Bernanke, Gertler, and Watson, 1997) have stressed not the direct effects of oil price increases on output and inflation, but possible indirect effects arising from the Federal Reserve's response to the inflation presumably caused by oil price increases.

A common thread in the popular press, in textbook treatments, and in the academic literature is that oil price shocks are an essential part of the explanation of stagflation. In contrast, in this paper we make the case that the oil price increases were not nearly as essential a part of the causal mechanism generating the stagflation of the $1970 \mathrm{~s}$ as is often thought. We discuss reasons for being skeptical of the importance of commodity supply shocks in general, and the 1973-1974 and 1979-1980 oil price shocks in particular, as the primary explanation of the stagflation of the 1970s. First, we show that there were dramatic and acrossthe-board increases in the prices of industrial commodities in the early 1970 s that preceded the OPEC oil price increases. These price increases do not appear to be related to commodity-specific supply shocks, but are consistent with an economic boom fueled by monetary expansion. Second, there is reason to doubt that the observed high and persistent inflation in the deflator in the early and late 1970s can be explained by the 1973-1974 and 1979-1980 oil price shocks. The argument that oil price shocks caused the Great Stagflation depends on the claim that oil price shocks are inflationary. Using a simple model, we show that a onetime oil price increase will increase gross output price measures such as the CPI, but not necessarily the price of value added, as proxied by the GDP deflator. Indeed, an oil price increase may lower the deflator. Further, the data show that only two of the five major oil price shocks since 1970 have been followed by significant changes in the inflation rate of the GDP deflator, though in all cases the CPI inflation rate changed sharply relative to the deflator. Although we come to the same conclu- 
sion as Blinder (1979) that oil caused a spike in consumer-price inflation during the two most stagflationary episodes, we show that oil prices do not provide a plausible explanation of the sustained inflation that occurred in the GDP deflator as well as in the CPI.

If oil price shocks were not the source of the Great Stagflation, what explains the striking coincidence of the major oil price increases in the 1970 s and the worsening of stagflation? In this paper we provide evidence that in the 1970s the rise in oil prices-like that in other commodity prices-was in significant measure a response to macroeconomic forces, ultimately driven by monetary conditions. This view coheres well with existing microeconomic theories about the effect of real-interest-rate variation and output movements on resource prices, and challenges the conventional wisdom that major oil price changes are largely exogenous with respect to macroeconomic variables of OECD countries. It is commonly held that major oil price movements are ultimately due to political events in the Middle East. Our analysis suggests that-although political factors were not entirely absent from the decision-making process of OPEC - the two major OPEC oil price increases in the 1970s would have been far less likely in the absence of conducive macroeconomic conditions resulting in excess demand in the oil market.

The prevailing view that exogenous oil price shocks were the primary culprits of the Great Stagflation of the 1970s goes hand in hand with the perception that monetary factors do not provide an adequate explanation of stagflation. In this paper we develop more fully a latent dissent to the conventional view that monetary considerations cannot account for the historical experience of the 1970s. ${ }^{2}$ Bruno and Sachs (1985) and, to a lesser extent, Blinder (1979, p. 77) discuss monetary expansion as one important source of stagflation, but their emphasis is on the inadequacy of money as an explanation of the bulk of stagflation and commodity price movements. ${ }^{3}$ In contrast, we show how in a stylized dynamic model of the macroeconomy stagflation may arise endogenously in response to a sustained monetary expansion even in the absence of supply shocks. The data generated by the model are broadly consistent, both qualitatively

2. References that we identify with the traditional view include Samuelson (1974), Blinder (1979), and Bruno and Sachs (1985). Precursors of our alternative explanation of stagflation and its association with oil prices include Friedman (1975), Cagan (1979), McKinnon (1982), Houthakker (1987), and De Long (1997).

3. For example, Bruno and Sachs $(1985$, p. 6) stress the inadequacy of purely demand-side models of stagflation and propose that contractionary movements in aggregate supply (such as oil price shocks) are needed to explain the slide into stagflation. Blinder (1979, pp. 102, 209) states that the inflation of 1973-1974 was simply not a "monetary phenomenon." As the causes of the inflationary surge in the mid-1970s, and also of the recession that followed, he identifies "special factors" such as food price shocks in 1972-1974, the oil price shock in 1973, and the dismantling of price controls in 1974. 
and quantitatively, with the dynamic properties of the actual output and inflation data for 1971-1975. Our model captures the notion that economic agents in the 1970s responded only gradually to shifts in the monetary policy regime. We link these shifts to the breakdown of the Bretton Woods system and to changes in policy objectives. Several indicators of monetary policy stance show that monetary policy in the United States, in particular, exhibited a go-and-stop pattern in the 1970s. Moreover, episodes of stagflation were associated with swings in worldwide liquidity that dwarf monetary fluctuations elsewhere in our sample.

The remainder of the paper is organized as follows. We begin with an outline of the basic facts of the stagflation of the 1970s in Section 2. Section 3 presents a monetary explanation of stagflation. In Section 4 we examine the empirical support for this monetary explanation, and in Section 5 the reasons for the shifts in monetary policy stance that in this view ultimately triggered the Great Stagflation. In Section 6 we discuss theoretical and empirical arguments against the oil-supply-shock explanation of stagflation. Finally, in Sections 7 and 8 we discuss the theoretical reasons for a close relationship between oil prices and macroeconomic variables and provide evidence that oil prices were in substantial part responding to macroeconomic forces, rather than merely political events in the Middle East. Additional evidence from the most recent oil price increase is discussed in Section 9. Section 10 contains the concluding remarks.

\section{Basic Facts}

This section describes some of the salient features of stagflation and of the evolution of oil prices in the postwar period. The 1970s and early 1980s were an unusual period by historical standards. Table 1 describes the pattern of inflation and of GDP growth for each of the NBER business-cycle contractions and expansions. For each phase, we present data on nominal GDP growth and its breakdown into real and price components. Two critical observations arise immediately from Table 1. First, with one exception, the phase average of the rate of inflation rose steadily from 1960.2 to 1981.2 , and declined over time thereafter. The exception is that inflation was 2.5 percentage points lower $(9.56 \%$ compared with $6.98 \%$ ) during the 1975.1-1980.1 expansion than in the preceding contraction period from 1973.4 to 1975.1 .

The second, and most important, observation is the appearance of stagflation in the data. Stagflation appears in Table 1 as an increase in inflation as the economy moves from an expansion to a contraction phase. There were three episodes in which inflation, as measured by the growth in the GDP deflator, was near $9 \%$ per annum. In two of these 
Table 1 REAL GROWTH, INFLATION, AND NOMINAL GROWTH IN THE UNITED STATES

\begin{tabular}{llccc}
\hline & & \multicolumn{3}{c}{ Percent change per annum } \\
\cline { 2 - 4 } $\begin{array}{l}\text { NBER business- } \\
\text { cycle dates }\end{array}$ & $\begin{array}{c}\text { State of the } \\
\text { economy }\end{array}$ & Real growth & Inflation & Nominal growth \\
\hline $1960.2-1961.1$ & Contraction & -1.03 & +1.22 & +0.19 \\
$1961.1-1969.4$ & Expansion & +4.64 & +2.59 & +7.23 \\
$1969.4-1970.4$ & Contraction & -0.49 & +4.93 & +4.44 \\
$1970.4-1973.4$ & Expansion & +4.34 & +5.22 & +9.56 \\
$1973.4-1975.1$ & Contraction & -1.76 & +9.56 & +7.80 \\
$1975.1-1980.1$ & Expansion & +3.80 & +6.98 & +10.78 \\
$1980.1-1980.2$ & Contraction & -3.46 & +8.88 & +5.42 \\
$1980.2-1981.2$ & Expansion & +0.62 & +9.11 & +9.73 \\
$1981.2-1982.4$ & Contraction & -1.34 & +6.07 & +4.73 \\
$1982.4-1990.2$ & Expansion & +4.07 & +3.29 & +7.36 \\
$1990.2-1991.1$ & Contraction & -1.27 & +4.12 & +2.85 \\
$1991.1-2001.1$ & Expansion & +3.46 & +2.10 & +5.56 \\
\hline
\end{tabular}

Source: Based on quarterly chain-weighted GDP and GDP deflator data from DRI for 1960.1-2001.1. The business-cycle dates are based on the NBER dating. The last expansion is incomplete.

three episodes real output contracted sharply (i.e., in 1973.4-1975.1 and 1980.1-1980.2), and in the third it grew very slowly (i.e., in 1980.21981.2). Indeed, in all but one contraction (i.e., with the exception of the second Volcker recession in 1981.2-1982.4), average inflation during the contraction was higher than during the previous expansion.

Figure 1 shows the percentage change in the nominal price of oil since March 1971, when the U.S. became dependent on oil imports from the Middle East (see Section 8). Episodes of so-called oil shocks are indicated by vertical bars and include the 1973-1974 OPEC oil price increase after the October war of 1973, the 1979-1980 price increases following the Iranian revolution in late 1978 and the outbreak of the Iran-Iraq war in late 1980, the collapse of OPEC and of the oil price in early 1986, the oil price spike following the invasion of Kuwait in 1990, and the most recent period of OPEC price management since March 1999. The coincidence of two large increases in the price of imported oil in the 1970s and two periods of strong stagflation has spurred interest in a causal link from "oil shocks" to stagflation, although casual inspection of Figure 1 and Table 1 suggests that this link is far less apparent for other episodes.

The decade of the 1970s also coincided with fundamental changes in monetary policy and in attitudes toward inflation, as the Bretton Woods system collapsed. Monetary policy became much more expansionary on average and more unstable in the 1970s than in the 1960s. One reason that these developments are often considered less important in discus- 
Figure 1 PERCENTAGE CHANGE IN NOMINAL PRICE OF OIL

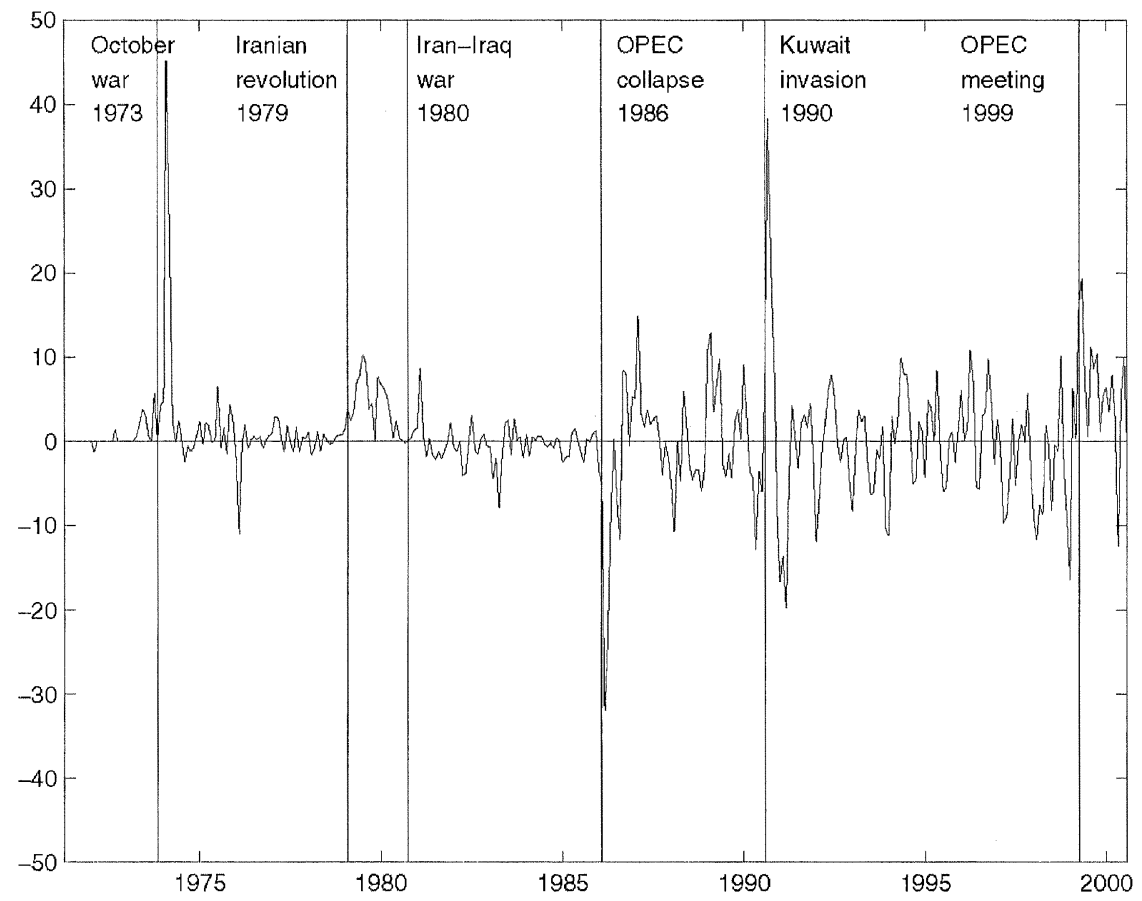

Source: The underlying oil price series is refiner's acquisition cost of imported crude oil (DRI code: EEPRPI) for January 1974 to July 2000. We use the U.S. producer price index for oil (DRI code: PW561) and the composite index for refiner's acquisition cost of imported and domestic crude oil (DRI code: EEPRPC) to extend the data back to March 1971.

sions of stagflation is the perception that monetary factors are unlikely to generate stagflation of sufficient magnitude (see Blinder, 1979). As we will show in Section 3, this perception is incorrect. Another reason for the popularity of the oil-price-shock explanation of stagflation is the fact that both the phenomenon of stagflation and that of major upheavals in the oil market occurred for the first time in the 1970s, although Table 1 suggests that stagflation predates the first oil price shock of late 1973. Although oil price shocks continue to occur, there have been no major episodes of stagflation since the 1970s.

In this paper we question the extent to which we really know that oil price shocks played a central role in generating stagflation. We will show that a monetary approach can explain not only the evolution of the Great Stagflation, but also that of the price of oil during that period. We will present a coherent explanation for the almost simultaneous occurrence 
of high oil prices and stagflation in the 1970s, and for the absence of such a relationship in subsequent periods.

\section{Purely Monetary Explanation of the Great Stagflation of the 1970s}

In this section, we describe a stylized monetary model that illustrates how substantial stagflation may arise even in the absence of supply shocks when inflation is inherently "sluggish" or persistent, and particularly when the monetary authority also follows a rule that prescribes a sharp contractionary response to increases in inflation. In this model as well as in the data, inflation continues to rise after output has reached its maximum and peaks only with a long delay. Impulse-response estimates from structural vector autoregressions (VARs) indicate that a monetary expansion is followed by a prolonged rise not just in the price level, but in inflation, a phenomenon that Nelson (1998) calls "sluggish inflation." Likewise, it is widely accepted that output exhibits a hump-shaped response to a monetary expansion. An important empirical regularity in VAR studies is that the response of output peaks after about 4-8 quarters, followed by a peak in inflation after about 9-13 quarters (e.g., Bernanke and Gertler, 1995; Christiano, Eichenbaum, and Evans, 1996; Leeper, 1997). Thus, the peak response of output occurs about one year before the inflation response reaches its maximum. ${ }^{4}$

What is the source of sluggish inflation? Sluggish inflation is not a property of the most commonly used monetary business-cycle models (Taylor, 1979; Rotemberg, 1982, 1996; Calvo, 1983). In these models, both inflation and output jump immediately to their maximal levels, followed by a monotonic decline. Although recent research has demonstrated the inconsistency of the Taylor-Calvo-Rotemberg model with the stylized facts about inflation and output dynamics (see Nelson, 1998), it has not provided a generally appealing alternative. In this paper, we take the position that sluggish inflation reflects the fact that agents learn only gradually about shifts in monetary policy (see Sargent, 1998). Agents are always processing new information, but especially so in a period following regime changes as dramatic as the changes that occurred in the 1970s. Given the low and stable inflation rates of the 1960s, it is plausible that agents were slow to revise their inflationary expectations when confronted with an unprecedented monetary expansion under Arthur Burns in the early 1970s. This interpretation appears even more plausi-

4. Nelson (1998) presents estimates that the response of inflation to a monetary innovation peaks after 13 quarters, but his VAR only includes money and the price level. 
ble considering the financial turmoil and uncertainty associated with the gradual disappearance of the Bretton Woods regime. Similarly, expectations of inflation were slow to adjust in the early 1980s, when Paul Volcker launched a new monetary policy regime resulting in much lower inflation.

We propose a stylized model that formalizes the notion that in times of major shifts in monetary policy inflation is likely to be particularly sluggish. Consider a population consisting of two types of firms. A fraction $\omega_{t}$ of "sleepy" firms is not convinced that a shift in monetary policy has taken place and sets its output price $\left(p_{t}^{s}\right)$ at last period's level adjusted for last period's inflation rate. The remaining fraction $1-\omega_{t}$ of "awake" firms is aware of the regime change and sets its output price at $p_{t}^{w w}=p_{t}+$ $\beta\left(y_{t}-y_{t}^{f}\right)$, where $\beta$ is a constant, $y_{t}$ the log of real GDP, and $y_{t}^{f}$ the log of potential real GDP. As time goes by, the fraction of agents that is unaware of the regime change evolves according to $\omega_{t}=e^{-\lambda t}$. These considerations imply an aggregate price-setting equation of the form

$p_{t}=\omega_{t} p_{t}^{s}+\left(1-\omega_{t}\right) p_{t}^{w}=e^{-\lambda t}\left(2 p_{t-1}-p_{t-2}\right)+\left(1-e^{-\lambda t}\right)\left[p_{t}+\beta\left(y_{t}-y_{t}^{f}\right)\right]$.

This price equation is the source of the inflation persistence in our model. Equation (1a) is very much in the spirit of Irving Fisher's (1906) reference to an earlier monetary expansion that "caught merchants napping." Its motivation is closer to that of the Lucas supply schedule (see Lucas, 1972, 1973) than to that of sticky-price models. Agents are always free to adjust prices without paying "menu costs." Moreover, by the choice of appropriate time-varying weights $\omega_{t}$, our inflation equation may allow for the fact that agents learn more quickly about some shifts in policy than about others. For expository purposes, however, we postulate that these weights evolve exogenously.

The second building block of the model is the equation

$$
\Delta y_{t}=\Delta m_{t}-\Delta p_{t}
$$

where $\Delta p_{t}$ is the inflation rate (which we will associate with the rate of change of the GDP deflator) and $\Delta m_{t}$ is the rate of nominal money growth. This relationship is a very simple money demand equation.

We complete the model by adding a policy reaction function. We posit that the Fed cannot observe the current level of the GDP deflator. We postulate a reaction function under which the Fed targets the rate of inflation. Let $\bar{\pi}^{\text {new }}$ be the steady-state rate of inflation consistent with the initial increase in money growth. That rate may be interpreted as the level of inflation that the Fed is willing to tolerate under the new expan- 
sionary regime. The Fed responds to periods of inflation in excess of $\bar{\pi}^{\text {new }}$ by decelerating monetary growth by some small fraction $\gamma$ of last period's excess inflation rate:

$$
\Delta^{2} m_{t}=-\gamma \Delta p_{t-1} I\left(\Delta p_{t-1}>\bar{\pi}^{\text {new }}\right)+\Delta \epsilon_{t}
$$

where $I(\cdot)$ denotes the indicator function, and $\epsilon_{t}$ represents the increase in the money growth rate associated with the Fed's more expansionary policy after the collapse of the Bretton Woods system. Note that, holding constant other demand shifters and given the sluggishness of inflation, this money growth rule may be translated into a more conventional interest-rate rule by inverting an IS curve and observing that high real balances imply low real interest rates. In addition, by way of comparison, we will explore a much simpler model in which money supply growth follows a sequence of exogenous policy shocks $\epsilon_{t}$ and in which there is no policy feedback:

$$
\Delta^{2} m_{t}=\Delta \epsilon_{t}
$$

The model is parametrized as follows. We postulate that in steady state output grows at $3 \%$ per annum. Moreover, prices grow at a steady rate of $3 \%$ per annum prior to the monetary expansion. We follow Kimball (1995) in setting $\beta=0.06$. The single most important parameter in the model is $\lambda$, which determines the fraction of agents "awake." We choose $\lambda$ to give our model the best possible chance to match the timing of business-cycle peaks and troughs in the U.S. inflation and output-gap data for 1971-1975. The resulting value of $\lambda=0.08$ implies that after two years slightly less than half of economic agents will have adopted the new pricing rule. This rate of transition may appear slow, but-as we will discuss below-is consistent with evidence from other sources as well. ${ }^{5}$ Finally, for the model with policy feedback, we choose $\gamma=0.05$ for illustrative purposes. This value means that, if, for example, the inflation rate last quarter is $2 \%$, the Fed will decelerate monetary growth by 0.1 percentage point (one-tenth of the initial monetary expansion). Our choice of $\gamma$ ensures that the inflation rate returns to the initial steady-

5. In our model it takes about two years for half of the agents to adopt the new pricing rule. This rate of adaptation may appear very slow, but it is not unlike those found in many other economic contexts. For example, data from the literature on the entry of lowerpriced generics into the market for branded drugs show that after two years only about half of the consumers have switched to the lower-priced generic drug (see Griliches and Cockburn, 1994; Berndt, Cockburn, and Griliches, 1996). If it takes so long for agents to adapt in such a simple problem, it does not appear implausible that it would take at least as long in our context. 
state rate in the long run. This choice is consistent with the interpretation that the Fed-rather than discovering a solution to the dynamic inconsistency problem-found its way back to low inflation using a mechanical rule (see Sargent, 1998).

Given this choice of parameters, consider a one-time shock to $\epsilon_{t}$ in period 5, representing a 4-percentage-point-per-annum increase in money growth, beginning in steady state. Figure 2a shows that a monetary expansion produces the essential features discussed above. The model economy displays stagflation, sluggish inflation, and a humpshaped response of output to a monetary expansion. Most importantly, the output gap rises with the inflation rate initially, with output peaking about two years after the shock, whereas inflation peaks only after three years (close to the 13 quarters reported by Nelson, 1998). Between these two peaks output and inflation move in opposite directions, resulting in stagflation.

We now address the extent to which this stylized monetary model can explain the business-cycle peaks and troughs over the 1971-1975 period. Consider the following thought experiment: Since we know that a strong monetary expansion took place starting in the early 1970s, we-somewhat arbitrarily-propose to date the monetary expansion in the model so that period 5 in Figure 2a corresponds to 1971.1. This thought experiment allows us tentatively to compare the behavior of output and inflation in the model in response to a monetary expansion with the actual U.S. data. Given this interpretation, the monetary model predicts a peak in GDP in 1972.4-1973.1, followed by a peak in deflator inflation in 1974.2 (shortly after the OPEC oil price increase) and a trough in GDP in 1975.2. Note that, although the NBER dates the end of the expansion in late 1973, Hodrick and Prescott (HP) detrended GDP peaks in 1973.1, at the same time as the gap peaks in our model. Thus, the timing of the cycle that would have been induced by the monetary expansion in 1971.1 (after allowing for the Fed's reaction to the changes in inflation set in motion by this initial expansion) is remarkably close to the timing of the actual business cycle. Note that this coincidence of the timing of the business-cycle peaks and troughs does not occur by construction, but arises endogenously given our choice of parameters.

Continuing with the same analogy, we now focus on the magnitude of the output and price movements induced by the monetary expansion. Of particular interest is the ability of the model to match the phase averages for 1971.1-1973.3 and for 1973.4-1975.1. We find that the average per annum inflation rates for 1971.1-1973.3 and 1973.4-1975.1 in the model are fairly close to the U.S. data. The model predicts average inflation rates of $5.1 \%$ and $10.4 \%$ per annum, respectively, compared 
Figure 2 IMPLICATIONS OF A PURELY MONETARY MODEL OF STAGFLATION: (a) WITH POLICY FEEDBACK; (b) WITHOUT POLICY FEEDBACK

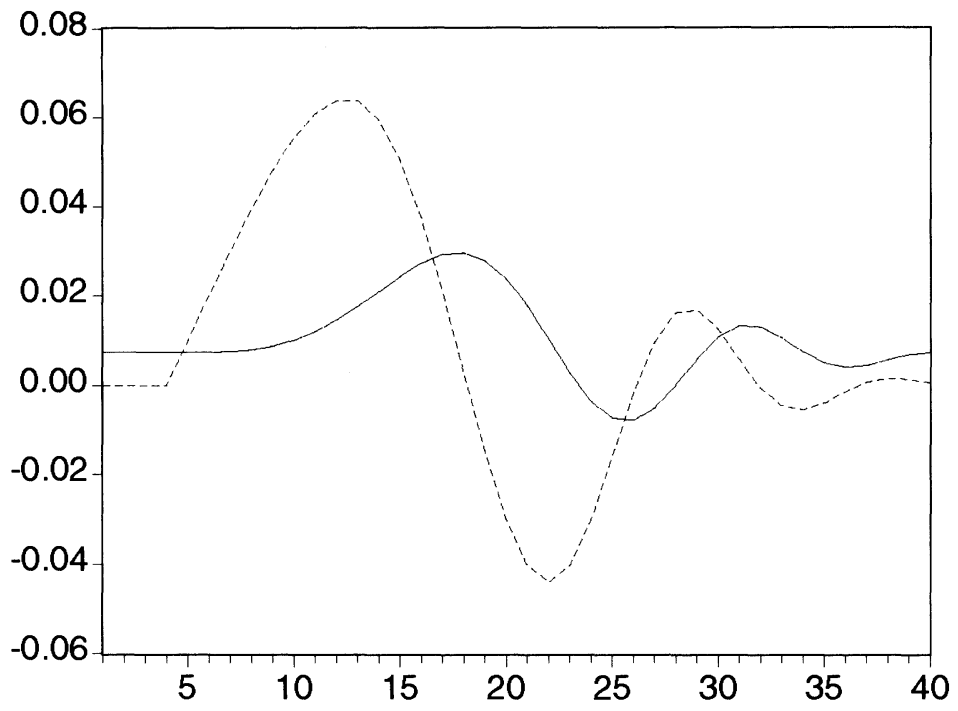

(a)

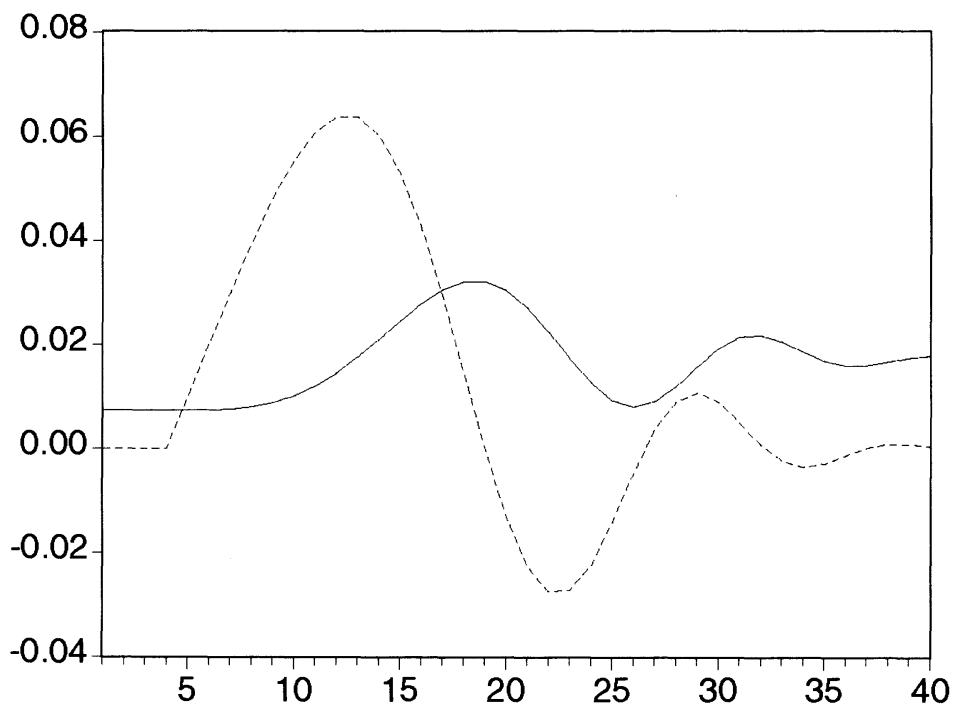

(b)

Notes: Solid curves: quarterly inflation rate. Dashed curves: output gap. Models described in text. Responses to a permanent 1-percentage-point increase in money growth in period 5. 
with $4.9 \%$ and $9.6 \%$ in the data. Thus, both the model and the data show a substantial increase in inflation during the recession. Similarly, for GDP growth the model fit is not far off. The model predicts $4.8 \%$ growth per annum for 1971.1-1973.3 compared with 5.2\% in the data, and $-3.0 \%$ for $1973.4-1975.1$ compared with $-1.8 \%$ in the data. We conclude that the quantitative implications of this model are not far off from the U.S. data, especially considering that we completely abstracted from other macroeconomic determinants. Also note that the Fed inflation target in our model economy becomes binding in early 1973 , consistent with the empirical evidence of a monetary tightening in early 1973 in response to actual and incipient inflation (see Section 4). This example illustrates that go-stop monetary policy alone could have generated a large recession in 1974-1975, even in the absence of supply shocks.

A question of particular interest is how essential the endogenous policy response of the Fed is for the generation of stagflation. Some authors have argued that the 1974 recession may be understood as a consequence of the Fed's policy response to inflationary expectations (e.g., Bohi, 1989; Barnanke, Gertler, and Watson, 1997). Figure $2 b$ shows that policy reaction is an important, but by no means essential, element of the genesis of stagflation. In fact, a qualitatively similar stagflationary episode would have occurred under the alternative policy rule $\left(1 c^{\prime}\right)$ without any policy feedback. The main effect of adding policy feedback $(\gamma>$ 0 ) is to increase the amplitude of output fluctuations and to dampen variations in inflation.

In the model without policy feedback, holding fixed the remaining parameters, the timing of the cycle induced by the monetary regime change is roughly similar to that in Figure $2 a$. Figure $2 b$ shows a peak in GDP in 1972.4-1973.1, followed by a peak in inflation in 1974.3 and a trough in GDP in 1975.2. The model without policy feedback predicts average annual inflation rates of $5.1 \%$ and $12.0 \%$ for $1971.1-1973.3$ and 1973.4-1975.1, respectively, compared with $4.9 \%$ and $9.6 \%$ in the U.S. data. Average output growth per annum over these same subperiods is $4.9 \%$ and $-2.0 \%$, respectively, in the model, compared with $5.2 \%$ and $-1.8 \%$ in the data.

The policy shift associated with the monetary tightening under Paul Volcker in late 1980 provides a second example of the basic mechanism underlying our stylized model. Using the same parametrization as for Figure $2 b$, our model predicts a sharp recession in late 1982, followed by an output boom in 1985 and an output trough in early 1987. This pattern closely mirrors the movements of HP-filtered actual output. At the same time, inflation in the model falls sharply, reaching its trough in 1984, 
followed by a peak in 1986. Actual inflation in the GDP deflator followed a qualitatively similar, but delayed pattern. It reached its trough in 1986, followed by a peak in mid-1988. Thus, the response of actual inflation in this episode is even more sluggish than that in the model.

\section{Support for the Monetary Explanation of Stagflation}

In this section, we will present four additional pieces of evidence in support of the monetary explanation of stagflation. First, we will examine several indicators of monetary policy stance to show that monetary policy in the United States, in particular, exhibited a go-and-stop pattern in the 1970s. Second, we will show that episodes of "stagflation" were associated with swings in world-wide liquidity which dwarf monetary fluctuations elsewhere in our sample. Third, we will show that there were dramatic and across-the-board increases in the prices of industrial commodities in the early 1970s that preceded the OPEC oil price increases. These price increases do not appear to be related to commodityspecific supply shocks, but are consistent with an economic boom fueled by monetary expansion. Finally, we will document that in early 1973 a broad range of business-cycle indicators started to predict a recession, nine months before the first OPEC oil crisis, but immediately after the Fed began to tighten monetary policy.

\subsection{EVIDENCE OF GO-AND-STOP MONETARY POLICY IN THE UNITED STATES}

Our evidence is based on two measures of the total stance of monetary policy for this period-one based on the behavior of the Federal Funds rate, the other based on narrative evidence (see Bernanke and Mihov, 1998; Boschen and Mills, 1995). The Bernanke-Mihov index of the overall monetary policy stance shows a strongly expansionary stance from mid-1970 to the end of 1972 (see Figure 3). Interestingly, the BoschenMills index, which is based on narrative evidence, is mostly neutral during this period with the exception of 1970-1971. The reason is that the Boschen-Mills index is based on policy pronouncements as opposed to policy actions. Quite simply, the Fed's pronouncements in this period were uninformative at best and probably misleading.

Both the Boschen-Mills index and the Bernanke-Mihov index show a sharp tightening of monetary policy in early 1973. The Boschen-Mills indicator, on a scale from +2 (very expansionary) to -2 (very tight), moves from neutral at the end of 1972 to -1 for the first three months of 1973. It then spends the next 6 months at -2 , followed by two months at -1 , ending the year in neutral. Further, the Bernanke-Mihov index shows a sharp and prolonged contraction in monetary policy by early 1973 
Figure 3 INDICATOR OF OVERALL MONETARY POLICY STANCE, JANUARY 1966 TO DECEMBER 1988

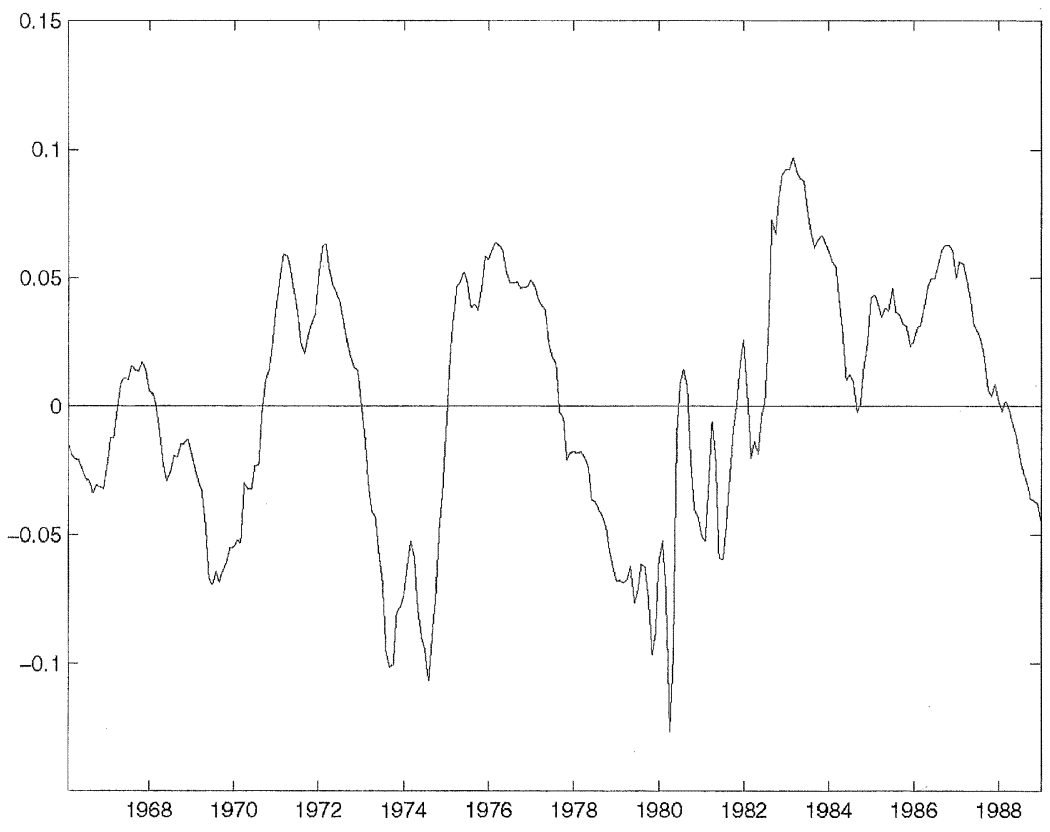

Source: Courtesy of B. Bernanke and I. Mihov.

(see Figure 3). ${ }^{6}$ As noted by Boschen and Mills (1995), this contraction was an explicit response to rising inflation. It occurred long before the disturbances in the oil market in late 1973 and provides an alternative explanation of the recession in early $1974 .{ }^{7}$ The contractionary response of the Fed in 1973 to the inflationary pressures set in motion by earlier Fed policy is a key element of our monetary explanation of stagflation. ${ }^{8}$ Note that the observed increase in inflation in 1973 is understated as a result of price controls, and the observed increase in 1974 is overstated due to the lifting of the price controls (see Blinder, 1979).

6. The downturn in the Bernanke-Mihov index in 1973 reflects a sharp rise in the Federal Funds rate. Interestingly, as Figure 5d shows, although the real interest rate rose, it remained negative throughout 1974 . Thus, the contractionary effect of the monetary tightening must have worked partly through other channels such as the effect of high nominal interest rates on housing starts in the presence of disintermediation due to interest-rate ceilings.

7. This interpretation is consistent with Bernanke, Gertler, and Watson's (1997) conclusion that the Fed in 1973 was responding to the inflationary signal in non-oil commodity prices, not to the oil price increase as is commonly believed.

8. There is no Romer date for 1973 , despite the clear evidence of a shift in policy toward a contractionary stance. 
As the U.S. economy slid into recession in 1974, the Fed again reversed course to ward off an even deeper recession. Indicators show a renewed monetary expansion that lasted into the late 1970s. The Bernanke-Mihov index indicates that monetary policy was strongly expansionary from late 1974 into 1977 (see Figure 3). This expansion was not initially reflected in high inflation, in line with our earlier discussion of sluggish inflation. Boschen and Mills record a similar, if somewhat briefer, expansion. Around 1978, the monetary stance turned slightly contractionary, becoming strongly contractionary in late 1979 and early 1980 under Paul Volcker, as inflation continues to worsen. Once again, the monetary policy stance provides an alternative explanation for the genesis of stagflation.

\subsection{WORLDWIDE CHANGES IN LIQUIDITY}

The changes in monetary policy indicators in the 1970s in the United States, and indeed in many other OECD countries, were accompanied by unusually large swings in global liquidity. One indicator of global liquidity is world money growth. We focus on world (rather than simply U.S.) monetary growth, both because the prices of oil and non-oil commodities are substantially determined in world markets, and becausedespite its origins in the U.S. - the monetary expansion in the early 1970s was amplified by the workings of the international monetary system, as foreign central banks attempted to stabilize exchange rates in the 1968-1973 period. The counterpart of the foreign-exchange intervention in support of the dollar was the paid creation of domestic credit in all of the large economies (see McKinnon, 1982; Bruno and Sachs, 1985; Genberg and Swoboda, 1993).

Figure $4 \mathrm{a}$ and $\mathrm{b}$ show a suitably updated data set for GNP-weighted world money growth and inflation, as defined by McKinnon (1982). There is evidence of a sharp increase in money growth in 1971-1972 and in 1977-1978 preceding the two primary stagflationary episodes in Table 1. The increase in world money growth is followed by a substantial rise in world price inflation in 1973-1974 and in 1979-1980 (see Figure 4b). The data also show a third major increase in world money-supply growth in 1985-1986. This does not pose a problem for the monetary explanation of stagflation, because $1985-1986$ is fundamentally different from 1973-1974 and 1979-1980. The coincidence of substantial money growth and low world inflation constitutes a partial rebuilding of real balances following the restoration of the commitment to low inflation. ${ }^{9}$

9. This is precisely the standard interpretation of the patterns of inflation and money growth that have been documented for the period following the monetary reform that ended the German hyperinflation (see Barro, 1987, p. 206, Table 8.1). 
Figure 4 MEASURES OF WORLD LIQUIDITY
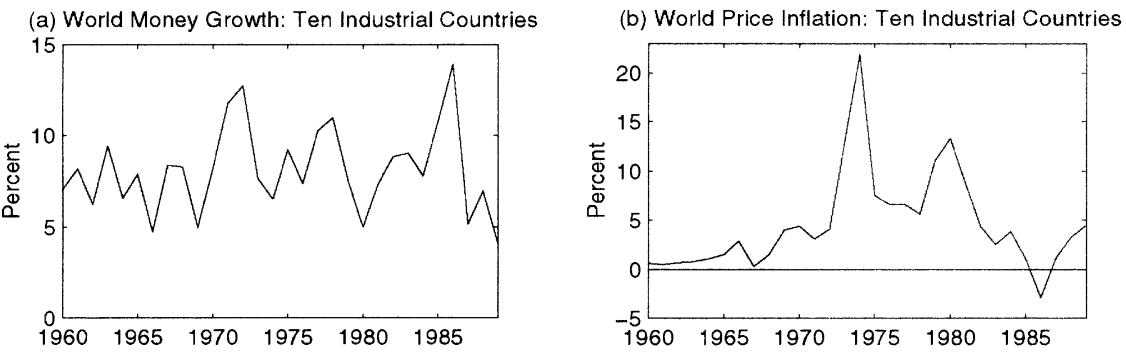

(c) Growth of World Real Balances: Ten Industrial Countries

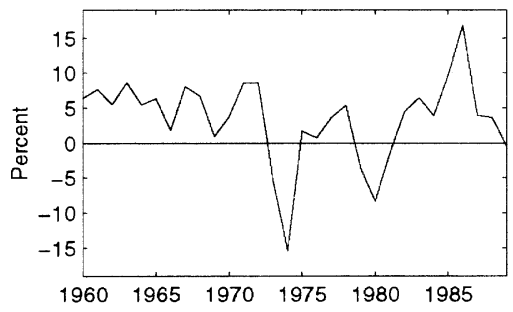

Source: Inflation and money are GNP-weighted growth rates per annum as defined by McKinnon (1982, pp. 322), based on IFS data for 1960.1-1989.4.

We now turn to the United States, where the monetary expansions of the 1970s originated. Figure 5 shows that U.S. liquidity followed a pattern similar to that of other industrial countries. Figure 5a shows two large spikes in money growth in 1971-1972 and in 1975-1977 that preceded two episodes of unusually high inflation in the GDP deflator in 1974 and in 1980 (see Figure 5b) and that coincided with two episodes of significantly negative growth in real money balances in 1973-1974 and 1978-1980 (see Figure 5c). Figure 5c also shows evidence of a rebuilding of real balances (and possibly of the financial deregulation) after 1980 .

Additional evidence of excess liquidity in the 1970s is provided by the behavior of the U.S. real interest rate. Figure 5d shows that 1972-1976 and 1976-1980 were periods of abnormally low real interest rates, followed by unusually high real interest rates in 1981-1986. This pattern is consistent with the view that the excess money growth in the early and mid-1970s depressed ex ante real interest rates via a liquidity effect and further depressed ex post interest rates by causing unanticipated inflation. The evidence in Figure 5d also is consistent with the view that the Fed in the 1970s followed an interest-rate rule that was more tolerant of inflation than would have been consistent with a Taylor rule as estimated over the 
Figure 5 MEASURES OF U.S. LIQUIDITY

(a) U.S. Money Growth

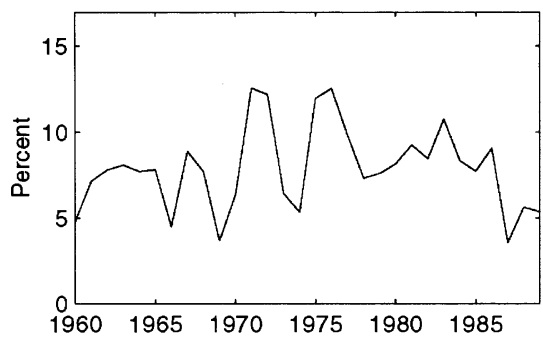

(c) Growth of U.S. Real Balances

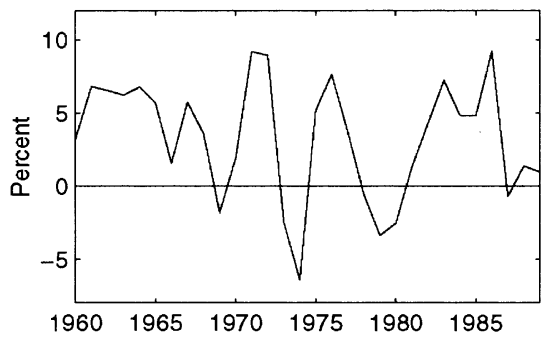

(b) U.S. Deflator Inflation

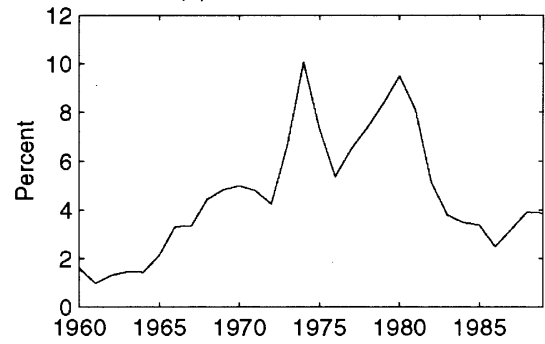

(d) U.S. Real Interest Rate

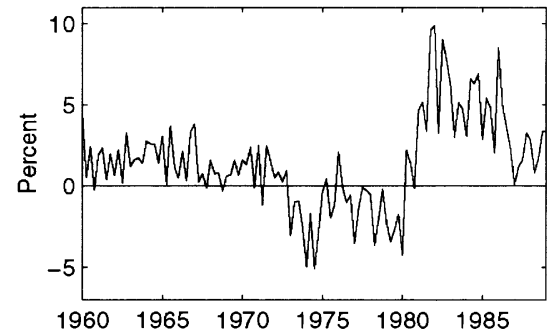

Source: (a) Based on DRI series FM2. (b) Based on DRI series GDPD. (c) Based on DRI series FM2 and PRXHS. (d) Based on DRI series FYGM3 and PRXHS.

Volcker-Greenspan period (see Clarida, Galí, and Gertler, 2000). Finally, the timing in Figure 5d contradicts the view that oil shocks were responsible for the low ex post real interest rates. Real interest rates were negative during 1973, after the evidence of excess money growth, but well before the two major oil price increases. In fact, the 1973-1974 and 1979-1980 oil price increases were followed by a rise in ex post real interest rates.

\subsection{MOVEMENTS IN OTHER INDUSTRIAL COMMODITY PRICES}

An important additional piece of evidence that has received insufficient attention in recent research is the sharp and across-the-board increase in industrial commodity prices that preceded the increase in oil prices in 1973-1974 (see Figure 6). These increases occurred as early as 1972, well before the October War, and are too broad-based to reflect supply shocks in individual markets. They are, however, consistent with a picture of increased demand driven by the sharp increase in global liquidity documented in Figure 3.

There is significant evidence that poor harvests caused food prices to soar in the early 1970s (see Blinder, 1979). Our data set deliberately 
Figure 6 NOMINAL PRICE INDEXES FOR CRUDE OIL AND FOR

INDUSTRIAL COMMODITIES, JANUARY 1948 TO JULY 2000

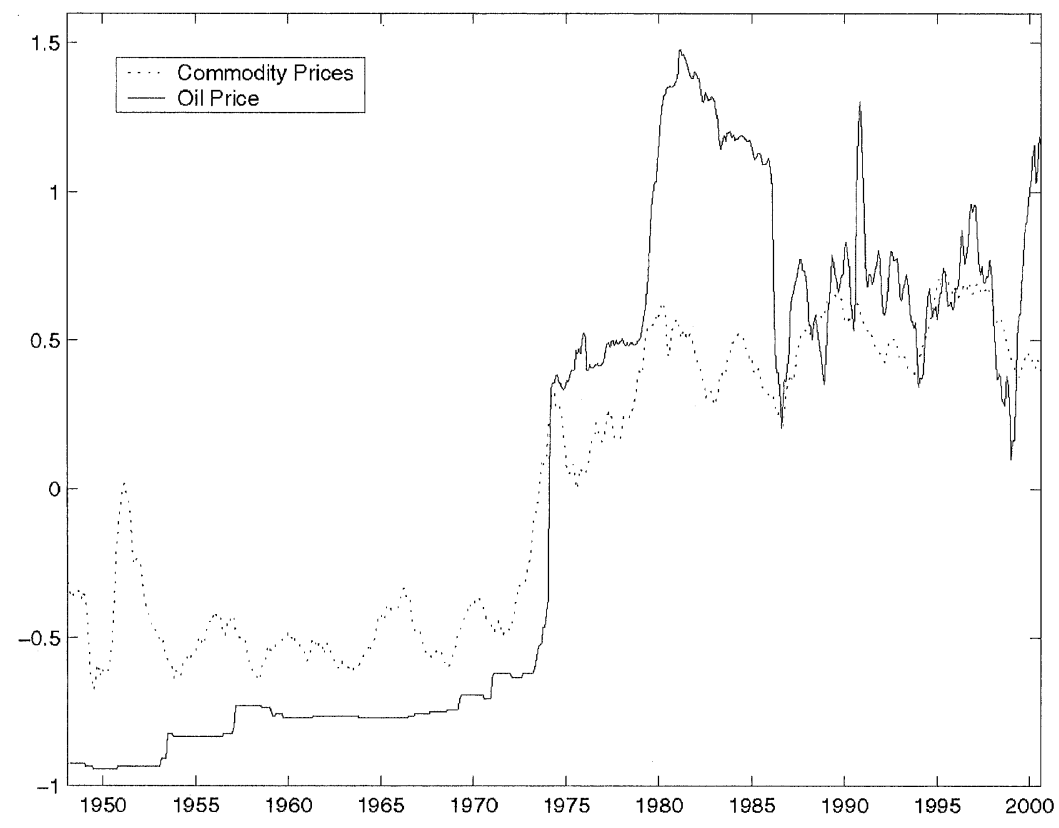

Source: All data are logged and de-meaned. The commodity price index excludes oil and food. The index shown is an index for industrial commodity prices (DRI code: PSCMAT). Virtually identical plots are obtained using an index for sensitive materials (DRI code: PSM99Q). The oil price series is defined as in Figure 1.

excludes food-related commodities. Instead, we focus on industrial raw materials. Commodities such as lumber, scrap metal, and pulp and paper, for which there is no evidence of supply shocks, recorded rapid price increases in the early 1970s (see National Commission on Supplies and Shortages, 1976). For example, the price of scrap metal nearly doubled between October 1972 and October 1973, and continued to rise until early 1974, to nearly four times its initial level. The price of lumber almost doubled between 1971 and 1974, as did the price of wood pulp. These commodity price data paint a picture of rapidly rising demand for all commodities in the early 1970 s.

It is interesting to note that a similar increase did not occur in oil prices until late 1973. Similarly, the 1979 increase in oil prices was preceded by a boom in other commodity prices, consistent with the evidence of monetary expansion, although the commodity price increase is of lesser magnitude. In fact, a striking empirical regularity of the data in Figure 6 is that 
increases in other industrial commodity prices tended to precede increases in oil prices over the 1972-1985 OPEC period (and similarly for decreases). This fact is evident for example in 1972, 1978, 1980, 1983, and 1984. A natural question is how the monetary explanation of stagflation proposed here can be reconciled with the delayed response of oil prices relative to other industrial commodities. The explanation appears to be that, unlike other commodity transactions, most crude-oil purchases until the early 1980s did not take place in spot markets, but at long-term contractual prices. The sluggish adjustment of these contractual prices in response to demand conditions in commodity markets tended to delay the response of the oil price relative to the price of more freely traded commodities, until the spot market largely replaced traditional oil contracts in the early $1980 \mathrm{~s}$.

\subsection{BUSINESS-CYCLE INDICATORS}

Finally, the monetary explanation is consistent with evidence of an impending recession long before the first oil price shock in October 1973January 1974, but shortly after the monetary tightening of early 1973 . Both the expected conditions component of the index of consumer confidence and the index of leading indicators peaked in January 1973, when monetary policy switched to a contractionary stance in response to rising inflation. Consumer durables started falling relative to trend in early 1973, as would be expected in response to a monetary tightening. Similar declines can be observed in the numbers of housing starts and motor-vehicle purchases. Figure 7 suggests that both consumers and economic forecasters were expecting a recession many months before the October 1973 war and the subsequent oil embargo, and that this expectation was not driven by concerns over OPEC. The decline in the index of leading indicators continued throughout 1974. Although we cannot tell to what extent the fall in the index of leading economic indicators after September 1973 can be attributed to oil as opposed to money, a full two-thirds of the fall in consumer confidence in 1973-1974 was completed prior to the oil date.

\section{What Explains the Initial Monetary Expansion of the 1970s?}

The U.S. economy moved from an extended period of low and stable inflation at the beginning of the 1960 s to one of high and variable inflation by the end of the decade. The underlying cause of the shift towards higher inflation was the gradual reduction in the United States's commitment to the twin goals of low and stable inflation and the avoidance of "excessive" balance-of-payments deficits. In the late 1960s, the central 
Figure 7 BUSINESS-CYCLE INDICATORS WITH OPEC I OIL DATES: (a) EXPECTED CONDITIONS COMPONENT OF CONSUMER CONFIDENCE; (b) REAL DURABLES CONSUMPTION (PERCENT DEVIATION FROM HP-TREND); (c) INDEX OF LEADING ECONOMIC INDICATORS

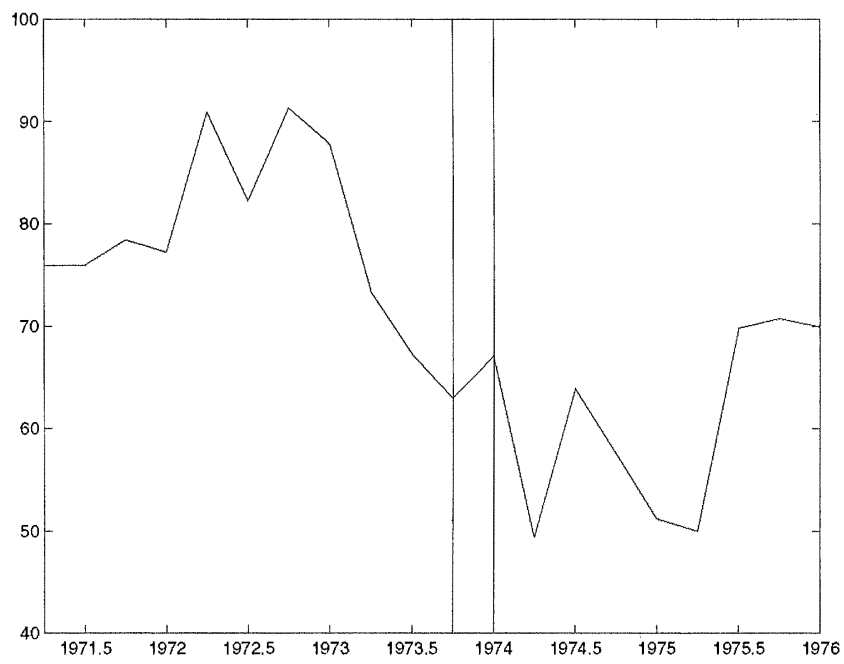

(a)

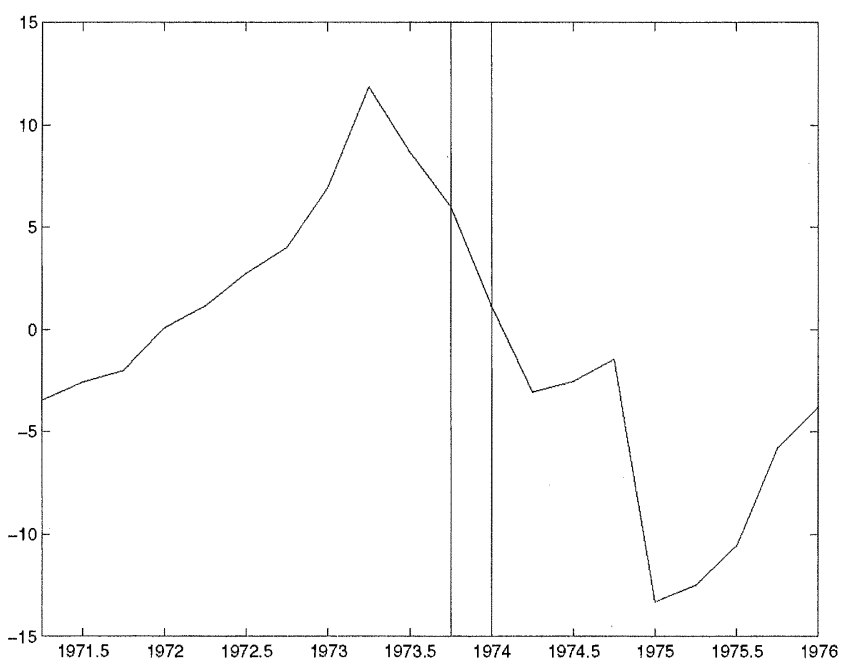

(b) 
Figure 7 CONTINUED

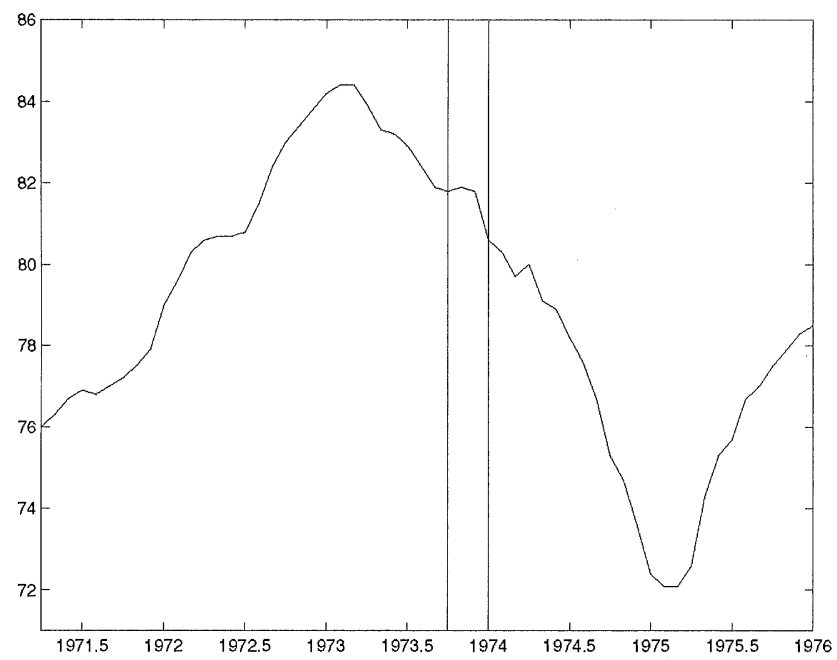

(c)

Sources: (a) Survey of Consumers, University of Michigan; (b), (c) based on DRI data.

bank's commitment to these traditional goals was increasingly diluted by the additional goal of maintaining high employment. ${ }^{10}$ The dilution of the commitment to controlling inflation and balance-of-payments deficits was behind both the weakening (and ultimately the destruction) of the Bretton Woods system and the initiation of expectations of high and persistent inflation in the late 1960s. The rise in inflationary expectations in turn triggered an inflation trap by raising the cost of subsequent disinflations (also see Christiano and Gust, 2000). ${ }^{11}$ These inflationary pressures were reinforced by two serious errors of economic analysis on

10. This change in focus can be traced ultimately to the Great Depression and the perception that tight monetary policy had been responsible for excessively high unemployment during the Great Depression. The rise in social and political commitment to full employment was furthered by an intellectual belief in the more or less permanent exploitability of the Phillips curve (see Samuelson and Solow, 1960). The refusal to rein in social spending or to allow a sharp rise in interest rates, as the Vietnam war expanded in the late 1960s, reflected the change in priorities.

11. What makes the expectations-trap hypothesis plausible is evidence that by 1971 the Fed indeed perceived a shift in the public's expectations of inflation. As Christiano and Gust (2000) note, Arthur Burns was concerned about expectations of inflation as early as December 1970. By 1971, he perceived a shift in inflationary expectation due to the steady rise of consumer-price inflation since 1965, well before the commodity supply shocks, the oil shocks, and the monetary expansion of the early 1970s (see Burns, 1978, pp. 118, 126). 
the part of the Federal Reserve: first, a miscalculation of full employment in the wake of the productivity slowdown and of structural changes in the labor market (see Orphanides, 2000; Orphanides et al., 1999); ${ }^{12}$ and, second, an increased tendency to attribute inflation to "special factors" rather than the underlying monetary environment. ${ }^{13} \mathrm{~A}$ third element was the exploitation of the newly unconstrained policy environment in the service of electoral politics. ${ }^{14}$

A number of authors (see McKinnon, 1982; DeLong, 1997; Mundell, 2000) have suggested that the collapse of the gold exchange standard associated with Bretton Woods played a key causal role in the creation of the inflationary monetary environment of the 1970s. ${ }^{15}$ Although it is widely accepted that the eventual collapse of the Bretton Woods system was inevitable due to fundamental structural flaws (see the papers in Bordo and Eichengreen, 1993), the timing of its demise was influenced by the same factors that also launched the initial wave of inflation in the mid-1960s to 1970. The collapse was triggered by an excess supply of U.S. dollars resulting both from the expansion of the U.S. monetary base and a reduction of the demand for dollars abroad driven by the expecta-

12. Orphanides (2000) documents that the measurements of real output available to the Fed following both the 1970 and 1974 recessions were substantially lower than the output data now available. At the same time, official estimates of potential real output were in retrospect far too optimistic, resulting in excessively high estimates of the output gap, defined as the shortfall of actual output relative to potential. Drawing on evidence from simulated real-time Taylor rules and on the Fed minutes and the recollections of the policymakers involved, Orphanides concludes that the increase in the natural rate of unemployment and the productivity slowdown in the late 1960s and 1970s were two major factors in explaining the inflationary outcomes of the period.

13. For example, Hetzel (1998) makes the case that then chairman Arthur Burns adhered to a special-factors theory of inflation which attributed increases in inflation to a variety of special circumstances ranging from unions and large corporations to government deficits and finally food and oil price increases. Hetzel argues that Burns systematically discounted any direct effects from increases in the money supply on inflation and did not appear to be overly concerned about the extent of the monetary expansion in the early 1970s. For a similar view see Christiano and Gust (2000).

14. For example, DeLong (1997) stresses that the inflation of the early 1970s was fueled in addition by Arthur Burns's efforts to facilitate Nixon's reelection through expansionary monetary policy. Christiano and Gust's (2000) narrative evidence that Burns was not intimidated by Nixon does not contradict this interpretation, because Burns's conservative economic views were closer to Nixon's than to those of his Democratic opponent.

15. The temporal coincidence is indeed an impressive one. The breakdown of the Bretton Woods system was foreshadowed by the introduction in 1968 of a two-tiered system of convertibility with significantly higher prices for private than for official transactions, in response to the declining private-sector confidence in the dollar peg. It became official when President Nixon announced the "closing of the gold window"-ending the convertibility of dollars into gold in August 1971. The relaxation of the convertibility constraint coincided with a dramatic increase in U.S. monetary growth (see Figure 3a) and a period of expansionary monetary policy between mid-1970 and late 1972, as indicated by the Bernanke-Mihov index. 
tion of an incipient depreciation of the dollar (see McKinnon, 1982; Bruno and Sachs, 1985; Genberg and Swoboda, 1993). In this sense, the breakdown of the Bretton Woods system was endogenous.

At the same time, awareness of the loss of prestige that would accompany suspension of convertibility continued until the end to serve as a partial commitment device that contributed significant restraint against higher inflation (see Bordo and Kydland, 1996). By completely removing this constraint, the 1971 closing of the gold window permitted a second round of monetary expansion starting from an already high base. In this sense, the breakdown of the Bretton Woods system may also be considered one of the causes of the monetary expansion. As stressed by Kydland and Prescott (1977) and Barro and Gordon (1983), the incentive of the central bank to stimulate employment in the short run tends to produce an excessively high rate of inflation in the absence of a suitable commitment mechanism. Not until the development of new commitment devices in the form of a lexicographic intellectual commitment to price stability and the cult of the conservative central banker at the beginning of the 1980s (see Rogoff, 1985) was the prevailing inflation reduced to the levels of the early 1960s. The reason that the 1970 s are different from the preceding and the following decade thus is the absence of effective constraints on monetary policy.

As the global monetary system underwent dramatic changes in the early 1970 s, both central bankers and private agents slowly had to adapt to the new rules of the game. The monetary expansion was not immediately understood by market participants and required a process of learning that is reflected in the sluggish adjustment of inflation in the model of Section 3. Furthermore, the Fed itself was operating in a new monetary environment without the traditional constraints and needed to learn about the consequences of its own actions. There was a widespread sense that "the rules of economics are not working in quite the way they used to" (see Burns, 1978, p. 118). This element of trial and error is important in understanding the go-and-stop nature of monetary policy in this period and helps to explain why the generally inflationary stance of monetary policy was punctuated by occasional sharp contractions. It also helps to answer the question why the Fed did not learn from its mistakes after the first episode of go-and-stop monetary policy ended in 1974. The data for U.S. monetary growth in Figure 5a show a renewed expansion that coincided with a period from late 1974 until 1977, in which policy indicators signal a second "go" phase for monetary policy. Part of the explanation may be that, at the time, the Fed attributed at least part of the observed stagflation to oil supply shocks and other special factors. More importantly, the Fed lacked a political mandate for 
serious reform. The lack of commitment to maintaining low inflation could only be overcome by the experience of double-digit inflation in the late 1970s. ${ }^{16}$

\section{How Convincing is the Aggregate-Supply-Shock Explanation of Stagflation?}

The view that the historical pattern of stagflation can be accounted for by the effects of money does not preclude the possibility that oil shocks played a major role in generating the stagflation either directly or indirectly by inducing a policy response. In this section, we will demonstrate that the supply-shock explanation of stagflation is less convincing than commonly thought.

\subsection{IS THE TEXTBOOK ANALYSIS OF AGGREGATE SUPPLY SHOCKS CONVINCING? GROSS VS. VALUE-ADDED CONCEPTS OF OUTPUT AND PRICE}

The textbook view is that oil price shocks are of necessity inflationary. The only question is the magnitude of the inflationary effect. As we will show, however, this claim is unambiguously true only for the price of gross output, not for the price of value added. The following counterexample demonstrates that oil price shocks may in fact have a deflationary effect on the price of value added, even as they raise the price of gross output.

Suppose gross output $Q$ is given by the production function $Y=Q[V(K$, $L, x), O]$, where $x$ denotes a technology disturbance, $O$ denotes the quantity of a foreign commodity import ("oil"), and $V(K, \mathrm{~L}, x)$ is domestic value added. As is standard, we assume separability between $O$ and the other factors in order to ensure the existence of a value-added production function. As is immediately clear, a decline in $O$, under separability, is not a shock to the production function for value added-the ability to produce domestic output is unchanged. It follows that oil shocks cannot play the role of a technology shock in a standard real-business-cycle model (i.e., they do not alter value added, holding constant capital and labor input), although they do lower the quantity of gross output.

Following Rotemberg and Woodford (1996), we consider an economy in which symmetric firms produce final output using the gross output production function

$Y_{t}=Q\left(V_{t}\left(L_{t}\right), O_{t}\right)$,

16. Sargent (1998) provides a detailed account of competing explanations of the transition back to a low-inflation regime. 
where $O_{t}$ is the quantity of foreign oil used in production, $Q$ is homogeneous of degree one in its arguments, and $V_{t}$ is a function of labor hours and capital. The capital stock is assumed to be fixed, ensuring concavity of $V_{t}$. Let gross output be the numeraire. $V_{t}$, the value added associated with capital and labor, should be thought of as real GDP. Nominal GDP is given by $P_{t} Y_{t}-P_{t}^{O} O_{t}$, where $P_{t}^{O}$ is the price of imported oil.

Further postulate that the demand for money balances is proportional to nominal gross output:

$$
M_{t}=k P_{t} Y_{t}
$$

where $P_{t}$ is the price of gross output. Thus, nominal gross output is determined by the money stock alone.

Now suppose that labor is supplied inelastically. Further suppose that all markets are perfectly competitive. Logarithmically differentiating (2) and (3) with respect to $P_{t}^{O}$, we obtain

$$
\begin{aligned}
& \Delta Y_{t}=-\frac{s_{O}}{1-s_{O}} \epsilon_{O, V} \Delta P_{t}^{O}, \\
& \Delta P_{t}=\frac{s_{O}}{1-s_{O}} \epsilon_{O, V} \Delta P_{t}^{O},
\end{aligned}
$$

where $\Delta$ denotes percent changes, $s_{O}$ is the cost share of oil in gross output, and $\epsilon_{O, V}$ is the elasticity of substitution between value added and oil. This means that an increase in the price of imported oil will tend to lower the quantity of gross output and raise the price of gross output.

Next consider the deflator for value added, defined as the ratio of nominal to real value added:

$$
P_{t}^{V}=\frac{P_{t} Y_{t}-P_{t}^{O} O_{t}}{V_{t}\left(L_{t}\right)}=\frac{P_{t} Y_{t}\left(1-s_{O}\right)}{V_{t}\left(L_{t}\right)}
$$

Again consider an increase in the price of imported oil. Clearly, under our assumptions the denominator of (6) does not vary with the price of oil. The numerator, however, will fall, since by (3) nominal gross output is determined solely by the money stock, and the cost share of imported oil in gross output is expected to rise in response to an oil price increase (see Gordon, 1984; Rotemberg and Woodford, 1996). Thus, the oil price shock lowers the price of value added, even as it raises the price of gross output. 
This stylized example illustrates that the aggregate-supply-shock analysis of oil price changes is questionable. Whereas aggregate-supply shocks in the textbook model are stagflationary for value added, oil price increases may actually be deflationary. In this sense, in our example they are closer in spirit to aggregate demand shocks than to aggregate supply shocks. ${ }^{17}$ How realistic is this counterexample? Clearly, to overturn our benchmark result would require a sufficiently sharp fall in real value added in response to an oil price shock, without a commensurate drop in the money stock. We now discuss several mechanisms by which oil price shocks may in principle generate a fall in the quantity of value added.

Since oil shocks are not productivity shocks, the key to establishing that oil price shocks affect value added then must be showing that labor and capital inputs change in response to an oil price shock. ${ }^{18}$ One model that establishes such a link is the sectoral-shifts model of Hamilton (1988). A related channel has been discussed by Bernanke (1983), who shows in a partial-equilibrium model that oil price shocks will tend to lower value added, because firms will postpone investment as they attempt to find out whether the increase in the price of oil is transitory or permanent.

Even if we accept the view that an oil price shock lowers real value added, however, there is no presumption that this shock will be stagflationary. First, consider the case of a fixed money supply. It is not enough to show that value added falls in response to an oil price shock. For the price of value added actually to rise when the money supply is fixed, value added must fall by more than the numerator in (6). More generally, the money supply will not be fixed. In that case, the direction of the change in the price deflator also depends on the Fed's reaction to the fall in value added. The optimal Fed behavior would be to contract the money supply in response to the fall in value added (see King and Goodfriend, 1997). We have already shown that indeed the Fed was conducting contractionary monetary policy at the time of the oil price

17. An additional factor that reinforces the aggregate-demand-shock interpretation is the transfer of purchasing power from the United States to OPEC (see Bruno and Sachs, 1985).

18. Under imperfect competition, as noted Rotemberg and Woodford (1996), an oil price shock does result in a rise in the supply price for all levels of value added. This increase occurs because firms apply the markup to all cost components, including imported oil, not just to capital and labor. The magnitude of this effect, however, is likely to be small for reasonable markup ratios, unless we allow in addition for substantial changes in the markup over time. The latter possibility is discussed by Rotemberg and Woodford (1996), who show that a model involving implicit collusion between oligopolists in the goods market can yield output responses to an oil price shock that are quantitatively important. 
shocks. Whether this monetary contraction would have been enough to stabilize the price level, as value added fell, is an empirical question. Either way, monetary policy plays a key role in determining the effect of oil price shocks on inflation.

This discussion shows that the implications of an oil price shock are unambiguous only for the price of gross output measures such as the consumer price index (CPI). Although one could construct other examples, in which oil price shocks are inflationary for the price of value added (measured by the GDP deflator), there is no presumption that in general they are. The direction and strength of the effect of oil price shocks on the GDP deflator is an empirical question.

\subsection{DO OIL PRICE SHOCKS MOVE THE GDP DEFLATOR?}

The preceding discussion stressed the important distinction between inflation in prices of gross output (such as the CPI) and of value added (such as the GDP deflator). In this section, we provide some empirical evidence about the timing and relative magnitude of the changes in the GDP deflator and the CPI inflation rates during major oil price changes that sheds light on the relative contributions of oil and money to the inflation in the GDP deflator observed in the 1970s. Figure 8 shows the annualized inflation rates for gross output prices (as measured by the CPI) and the price of value added (as measured by the GDP deflator) for the United States in the period 1960.1-2000.2. ${ }^{19}$ We use the PRXHS index of consumer prices, which excludes housing and shelter. Despite the obvious differences in the content and construction of these two indices, there is strong comovement in the long run. For our purposes, it will be of interest to focus on five major episodes: the two major oil prices increases of 19731974 and 1979-1980, the major drop in oil prices in early 1986, the invasion of Kuwait in 1990-1991, and the recent oil price volatility since 1997.

Our first observation is that Figure 8 shows an unusual discrepancy between the deflator and CPI inflation rates during each of the five episodes of interest. CPI inflation rose sharply relative to deflator inflation between 1972 and 1974 and again in 1979 and early 1980. This result is not surprising, as these periods were characterized by major fluctuations in world commodity markets. To the extent that prices of imported

19. Our theoretical counterexample maintained the implicit assumption that no oil is produced domestically. This is not an issue for most OECD countries in the 1970s with the exception of the United States. There are reasons to doubt the quantitative importance of this channel, however, even for the United States, given the small share of domestic oil in U.S. GDP. It may be shown that the inflation rate for the non-oil component of U.S. GDP will be lower than the inflation rate for the total GDP deflator, but that the overall results are qualitatively similar under realistic assumptions. 
Figure 8 QUARTERLY U.S. INFLATION RATES FOR 1960.1-2000.2

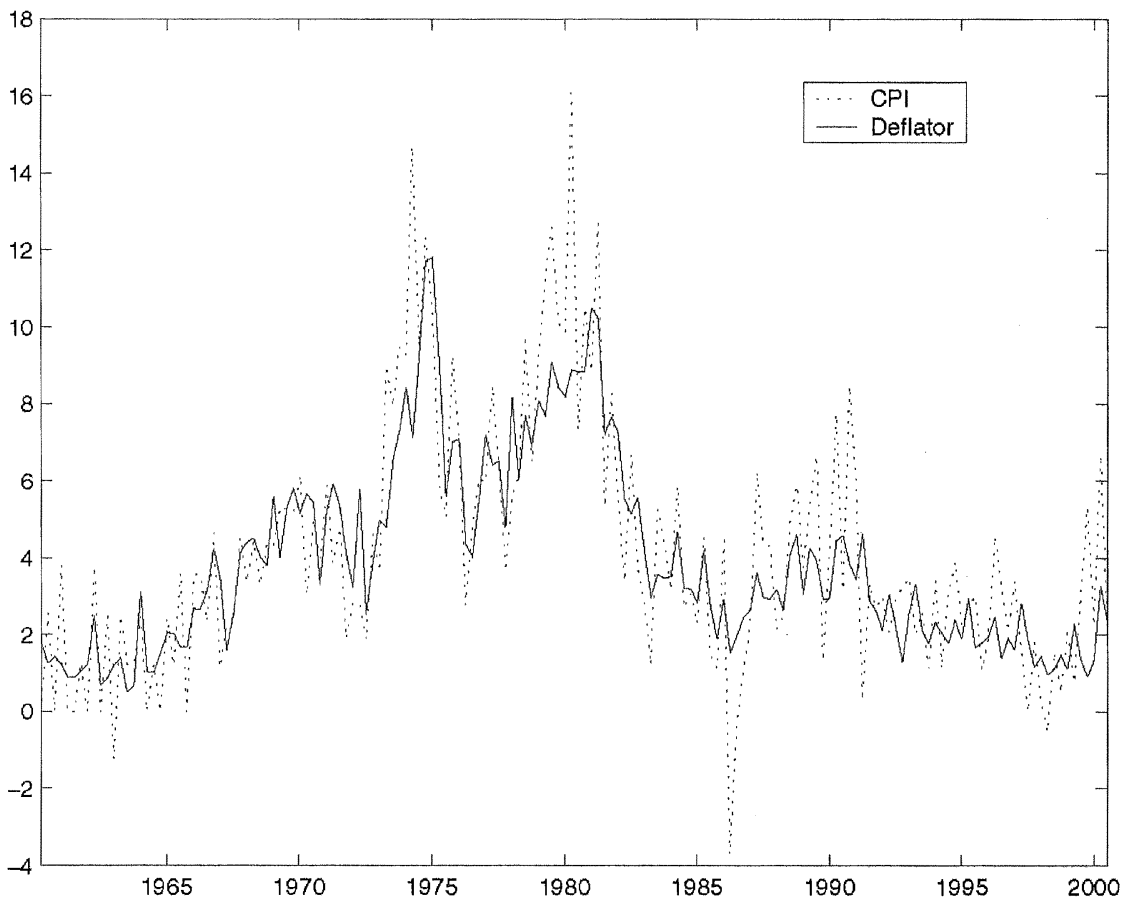

Source: All data are growth rates per annum. All data are taken from the DRI database. We use PRXHS (consumer prices excluding shelter) as the CPI measure, and GDPD as the implicit GDP deflator.

oil and other imported commodities enter the CPI but not the deflator, our earlier discussion suggests that we should expect to see a wedge between inflation in the CPI and in the deflator. Moreover, it is well known that especially price-sensitive items such as food (whether imported or not) have higher weights in the CPI than in the deflator, adding to the discrepancy. Similarly, the 1986 and 1990-1991 episodes are characterized by a differential response of CPI and deflator inflation rates. The same differential response occurs after 1997, as oil prices first plummet and then experience a dramatic reversal in 1999 and 2000.

Our second observation is that during the 1970s increases in CPI inflation rates tended to precede increases in the inflation rate of the deflator. Although CPI inflation reached double-digit rates in early 1974, the bulk of the inflation in the deflator only occurred from mid-1974 to 1975. Similarly, although CPI inflation rates rose sharply in 1979-1980, the bulk of the increase in the inflation in the deflator occurred only in mid- 
$1980-1981 .{ }^{20}$ One possible explanation for this difference in timing is that value added fell for the reasons described by Hamilton (1988), and monetary policy did not contract enough to prevent an increase in the price level. An alternative explanation is that the delayed inflation was caused by the earlier monetary expansion. The latter explanation seems more plausible, given that of the five oil episodes in our sample period only the 1973-1974 and 1979-1980 episodes are associated with large changes in the deflator inflation rate-but none of the other major oil price changes.

Of particular interest is the 1986 fall in the oil price following the collapse of OPEC. The fact that the sharp deflation in the CPI in 1986 was accompanied by only a minor reduction in deflator inflation casts doubt on the view that oil was responsible for deflator inflation in earlier periods. Similarly, during 1990-1991 deflator inflation changed little by historical standards. Further evidence against the oil-supply-shock view of stagflation is provided by the events of 1997-2000. During this period oil prices first fell sharply to an all-time low and then rose sharply to heights not seen since 1979-1980. As expected, these oil prices swings are reflected in considerable swings in CPI inflation rates in Figure 8, but they have little, if any, effect on deflator inflation.

Figure 8 illustrates that the high correlation of oil price shocks and subsequent increases in deflator inflation that we observe in the 1970s breaks down in other periods. We interpret this evidence as supportive of the view that this relationship is largely coincidental. The monetary explanation of stagflation provides a coherent account of why the 1970s were different, and of what generated the observed dramatic increases in deflator inflation. Thus, the evidence in Figure 8 provides further support for the monetary explanation of the stagflation of the 1970s.

\section{The Relationship of Oil Prices and the Macroeconomy: Theory}

In Section 6, we showed that, although an oil supply shock may well cause a recession, its effect on the GDP deflator (as opposed to the CPI) is ambiguous in theory and appears to be small in practice. Nevertheless, casual observers continue to be impressed with the coincidence of sharp oil price increases in the 1970s and the worsening of stagflation. In

20. The unusually long delay in the response of inflation to money can be explained by the presence of wage and price controls throughout 1973 and in early 1974. These controls effectively suppressed inflation rates. The lifting of price controls in April 1974 coincided with a sharp increase in deflator (as well as CPI) inflation (see Blinder, 1979). The fact that the increase in deflator inflation rates in 1980-1981 was smaller (if more sustained) than in 1974-1975 also is consistent with this interpretation. 
fact, some observers seem puzzled by the absence of a close link between oil prices and stagflation at other times (for example, The Economist, 1999).

In this section, we will argue that the almost simultaneous occurrence of sharp increases in oil prices and worsening stagflation in the 1970s was indeed no coincidence. Unlike conventional accounts based on exogenous oil supply shocks, however, we stress that oil prices were responding in substantial measure to conditions in the oil market, which in turn were greatly affected by macroeconomic conditions (and ultimately by the monetary stance). Put differently, we reject the common notion of a simple one-way causal link from oil prices to the macroeconomy and allow for the possibility that oil prices (like other commodity prices traded in international markets) tend to respond to macroeconomic forces.

The view that oil prices contain an important endogenous component is not as radical as it may seem. In fact, the observed behavior of oil and non-oil commodity prices coheres well with economic theory about resource prices (see Heal and Chichilnisky, 1991). Commodity prices rise in response to high output and low real interest rates. Our emphasis on the endogenous response of oil prices to global (and in particular U.S.) macroeconomic conditions does not rule out that political events played a role in the timing of the observed oil price increases, but it suggests that politically motivated increases in the oil price would have been far less likely in the absence of a conducive economic environment created by monetary policy.

The starting point for our analysis is the classic resource extraction model of Hotelling (1931). Applying this model to oil, marginal revenue (MR) net of marginal cost of extraction (MCE) must rise at the rate of interest, so that well owners are on the margin indifferent between extracting oil today and extracting oil tomorrow. Further, the transversality condition says that, in the limit, no oil should be wasted. Combining these two conditions, for the special case of zero marginal extraction cost, we have

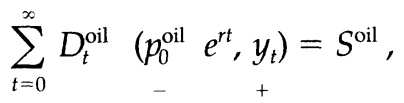

where $p_{0}^{\text {oil }}=$ initial relative price of oil, $S^{\text {oil }}=$ fixed stock of oil, $r=$ real interest rate, $y_{t}=$ aggregate output in period $t$, and $D_{t}^{\text {oil }}=$ demand for oil in period $t$. Under perfect competition, equation (7) implies that the price of oil rises at the rate of interest until the fixed stock of oil is exhausted. For the more general case of positive marginal extraction costs the first- 
order condition for profit maximization is that MR - MCE must rise at rate $r$ :

$\frac{\dot{M} R-M \dot{C} E}{M R-M C E}=r$.

Note that the required rise over time in MR - MCE may be accomplished by a fall in MCE as new capacity is developed, even without a rise in the oil price (see Holland, 1998). Indeed, this feature of the model allows for the oil price to fall over time.

This simple model implies several channels through which monetary policy affects oil prices. First, a one-time permanent drop in $r$ raises the initial price, and implies slower price growth thereafter. Second, a rise in aggregate real income shifts out the flow demand for oil. Since the oil is consumed more rapidly, the price of oil must rise to clear the market. The magnitude of these effects depends on the size and duration of the effects of monetary policy on $r$ and $y$. Money is not normally thought to permanently change $r$ or $y$. Thus, the magnitude of price adjustment in response to monetary policy in this model may not be large. Much stronger effects on the price of oil may occur once capacity is modeled explicitly.

If marginal costs are increasing in the extraction rate (which-in the limit-may be interpreted as a capacity constraint), a shift in demand for oil in this model may generate sharp increases in the price of oil as well as overshooting of the oil price. ${ }^{21}$ In the limit, if installed capacity is instantaneously fixed, the price of oil at a moment in time is determined entirely by demand. A rise in real GDP, or a decrease in the real interest rate, shifts the demand curve for oil to the right, sharply raising the market price of the given stock of oil. However, this price increase carries the seeds of its own destruction. If we began in steady state, the shadow price of capacity will now exceed its replacement cost at current levels of capacity. If the price remains high for extended periods, investment in drilling and distribution capacity takes place, and in the long run the price of oil will fall.

In addition to the direct effects of real income and real interest rates on the demand for oil, there is also an additional effect that links the stabil-

21. Mabro (1998, p. 16) notes that ". . exhaustibility as an ultimate outcome in a universal context is not very relevant [for the oil price] because the time horizon involved, even today, is far too long to have a noticeable impact. What matters is the relationship of current productive capacity to current demand and of planned investments in capacity to future demand. It is not the geo-physical scarcity of oil that poses problems . . . but the capacity issued at any given point in time." 
ity of oil cartels to macroeconomic forces. Standard theoretical models of cartels such as Rotemberg and Saloner (1986) and Green and Porter (1984) predict that cartel stability will be strengthened by low real interest rates. Producers trade off the immediate gains from abandoning the cartel against the present value of the cartel rents forgone. This logic suggests that the unusually low real interest rates in the 1970s, all else equal, should have been conducive to the formation of cartels, and the high real interest rates of the 1980s should have been detrimental. Moreover, Green and Porter show that if producers, rather than observing the cartel's output, only observe a noisy measure of the market-clearing price, cartel activity will be procyclical. The assumption of imperfectly observable output is particularly appealing for crude-oil producers. The actual production level of crude oil can only be estimated in many cases, and reliable output statistics become available only with a long lag. Thus, we would expect strong economic expansions, all else equal, to strengthen oil cartels and major recessions to weaken them.

\section{The Relationship of Oil Prices and the}

\section{Macroeconomy: Evidence}

The view that oil prices are endogenous with respect to U.S. macroeconomic variables such as real interest rates and real GDP has considerable empirical support. The two most prominent increases in the price of oil in 1973-1974 and 1979-1980 were both preceded by periods of economic expansion (see Table 1) and unusually low real interest rates (see Figure 5d). Similarly, the most recent oil price increase coincided with a strong economic expansion. In contrast, the fall in oil prices after 1982 coincided with a severe global recession and unusually high real interest rates. This section analyzes in detail the historical evidence for a link between oil prices and the macroeconomy.

\subsection{WHY DID THE 1973-1974 OIL PRICE INCREASE OCCUR WHEN} IT DID?

An intriguing question is why the two major and sustained oil price increases of the 1970s occurred when they did. The dominant view in the literature appears to be that the timing was primarily determined by exogenous political events in the Middle East, which are thought to have triggered supply cuts, thereby raising oil prices (see Hamilton, 1999). However, as we will argue, sustained oil price increases are only possible under conditions of excess demand in the oil market. Such conditions are unlikely to occur in the absence of favorable macroeconomic conditions, notably economic expansion and low real interest rates. 
Thus the apparent success of OPEC oil producers in raising prices in the 1970s (and their failure to raise prices for sustained periods at other times) is no historical accident. The timing of the oil price increases in the 1970s coincided with periods of unusually strong demand for oil, driven in substantial part by global macroeconomic conditions.

Until the late 1960s, the excess capacity of the U.S. oil industry allowed the U.S. to play the special role of the supplier of last resort to Europe and Japan, in the event that oil supplies were threatened. The fact that the U.S. assumed this role was an inadvertent consequence of the regulatory policies of the Texas Railroad Commission regime, under which rationing of production led to excess capacity (see Hamilton, 1985). The ability of the United States to flood the market with surplus oil served as a deterrent against any attempt to raise international oil prices, and ultimately thwarted the effects of the 1956 and 1967 oil embargoes. What then were the changes in the world oil market that made the successful 1973 oil price hike possible? The main difference between the early 1970s and earlier periods was that, on top of the long-term trend toward increased energy consumption, there was a dramatic surge in worldwide demand for oil that was fueled by monetary expansion.

In March 1971, U.S. oil production for the first time in history reached $100 \%$ of capacity (see Yergin, 1992, p. 567). ${ }^{22}$ The rising demand for oil was at first met with an increase in oil output in the Middle East that kept the price of oil low and falling in real terms (see Figure 9). Oil imports as a share of U.S. oil consumption rose from 19\% in 1967 to $36 \%$ in 1973 (see Darmstadter and Landsberg, 1976, p. 31). Mabro (1998, p. 11) notes that OPEC's average daily production increased from 23.4 million barrels per day in 1970 to 30.99 million barrels per day in 1973. All OPEC members but Kuwait, Libya, and Venezuela increased production in this period. As a result, excess capacity was shrinking quickly in the Middle East.

Seymour (1980, p. 100) documents that the oil market had been tightening since 1972 in spite of the rapid increases in oil output. In late 1972, all of the main market indicators-tanker freight rates, refinedproduct prices, and spot crude prices-started rising and continued their climb throughout 1973. While the recoverable reserves in the Middle East were of course huge, available production capacity was lagging consumption. By September-October of 1973, immediately before the

22. The normal market response to this shortage would have been rising oil prices. However, U.S. price controls on oil, imposed in 1971 as part of an overall anti-inflation program, were discouraging domestic oil production while stimulating consumption, and left little incentive for exploration or conservation. Moreover, growing environmental concerns held back U.S. oil production, even as new large oil reserves were being discovered in Alaska (see McKie, 1976, p. 73). 
Figure 9 REAL PRICE INDICES FOR CRUDE OIL AND FOR INDUSTRIAL COMMODITIES, JANUARY 1948 TO JULY 2000

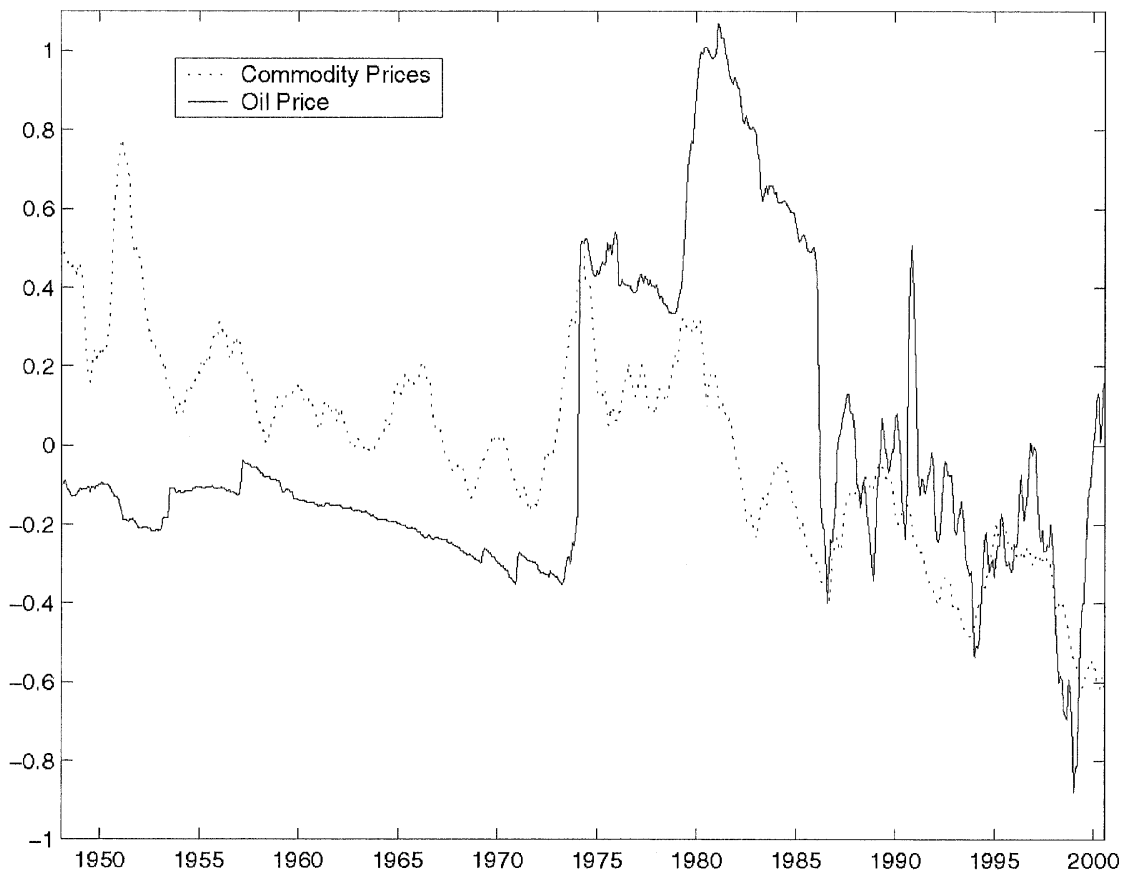

Source: See Figure 6 for a description of the data. The price data have been deflated using the CPI index excluding shelter (PRXHS).

oil embargo, both Saudi Arabia and Iran had just about reached their maximum sustainable output. The capacity shortage was not limited to Saudi Arabia and Iran. Had oil prices not risen in late 1973, there would have been virtually no spare productive capacity available anywhere in the world on the basis of the then projected forecasts of oil consumption for the winters of 1973-1974 and 1974-1975 (see Seymour, 1980 , p. 100). ${ }^{23}$

23. Our reading of the evidence coincides with contemporary accounts. For example, in November 1968, only one year after the successful defeat of the 1967 oil embargo, State Department officials announced at an OECD meeting that soon the U.S. would not be able to provide extra supply to the world in the event of an embargo (see Yergin, 1992, p. 568). In November 1970, a U.S. diplomat in the Middle East filed a report stating that "the extent of dependence by western industrial countries upon [foreign] oil as a source of energy has been exposed, and the practicality of controlling supply as a means of exerting pressure for raising the price of oil has been dramatically demonstrated" (Yergin, 1992, p. 587). 


\subsection{IF THE 1973 OIL PRICE INCREASE WAS CAUSED BY DEMAND SHIFTS, WHY DID OIL OUTPUT FALL?}

The normal market reaction to the increased demand for oil in the early 1970s should have been an increase in both price and quantity of oil. As we have noted, the data instead show a steady decline of the price of oil in real terms in the early 1970s, followed by a sharp rise in the price of oil in late 1973 and a drop in oil output. This puzzling observation reflected the gradual resolution of a disequilibrium that arose from the peculiar institutional structure of the OPEC oil market at that time.

Throughout the 1960s, oil delivery contracts were long-term agreements between OPEC producers and oil companies. Oil producers agreed to supply oil at a price that was fixed in nominal terms for several years in advance. Contracts were periodically renegotiated to take account of changes in economic conditions. As the macroeconomic environment became increasingly unstable in the early 1970s, the renegotiations failed to keep pace with the rapidly changing macroeconomic conditions. The stickiness of the nominal oil price contributed to the observed fall of the real price of oil, as inflation outpaced expectations. OPEC producers became increasingly reluctant to supply additional quantities of oil at prices well below the market-clearing level.

By late 1973 this regime came to an abrupt end, when OPEC reneged on its contractual agreements with the oil companies and unilaterally decreed a much higher price of oil. As the price of oil rose sharply, the quantity of oil fell, lending credence to the view that a contemporaneous shift in the supply of oil had taken place. It is common to attribute the fall in oil output and the rise in the price of oil to the 1973 war and the subsequent oil embargo (see Hamilton, 1999). As we will show, this interpretation is by no means obvious, because excess demand in the oil market would have induced an unprecedented increase in oil prices at the end of 1973, even in perfectly competitive markets.

For expository purposes consider a two-period model of the oil market dynamics in the early 1970s (see Figure 10). In period 1, starting from the equilibrium point $A$, a shift in demand for oil as a result of expansionary monetary policy raises the shadow price for oil. The new market-clearing price at point $B$, however, is never realized, because the price of oil is effectively held back by long-term contractual agreements (see Penrose, 1976). ${ }^{24}$ Instead, we move from $A$ to $C$, corresponding to an increase in

24. The essential point here is that the price of oil in the early 1970 s remained substantially below market-clearing level in the presence of excess demand. The assumption of a fixed price is an oversimplification designed to allow us to abstract from the effects of inflation. The price of oil actually fell in real terms in the early 1970s, despite efforts by OPEC to offset these losses (see Figures 6 and 9). 
Figure 10 A TWO-PERIOD DISEQUILIBRIUM ANALYSIS OF THE OIL MARKET

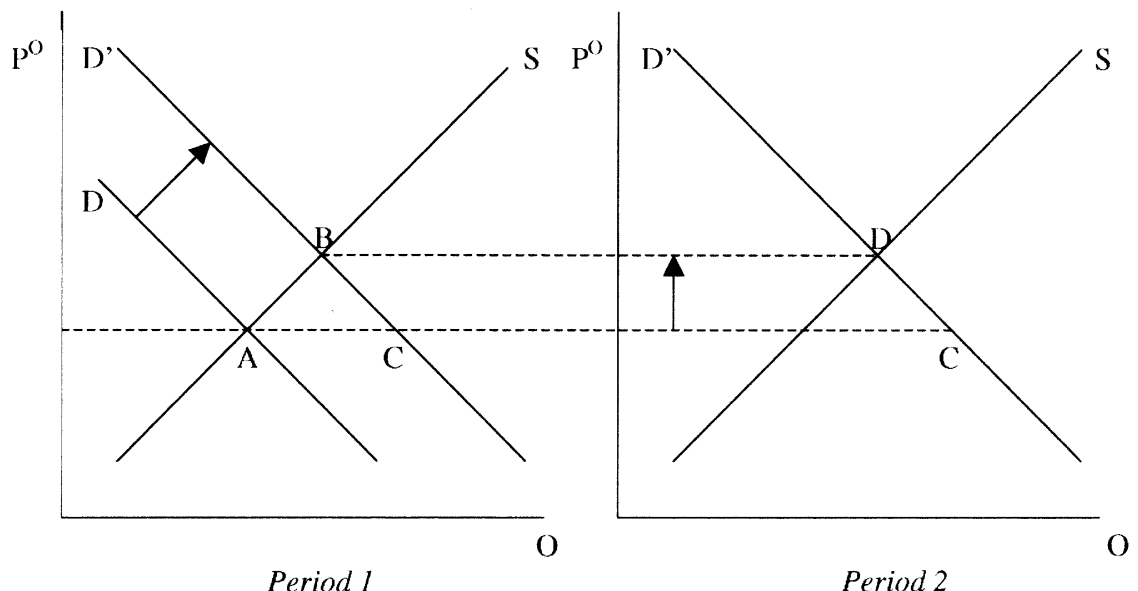

Notes: In period 1, starting from the equilibrium point $A$, a shift in demand for oil as a result of expansionary monetary policy raises the shadow price for oil. Given the fixed contractual price of oil, production increases and we move to $C$. In period 2, OPEC reneges on the contractual price, and raises the oil price to the market-clearing level $D$ while reducing the quantity supplied.

the quantity of oil supplied at the old price. In period 2, OPEC reneges on the contractual price, and raises the oil price to the market clearing level $(D=B)$ while reducing the quantity supplied. The price and quantity movements in period 2 have the appearance of an oil supply shock, yet the supply curve never shifts; we are witnessing the correction of a disequilibrium resulting from the earlier demand shift.

Our stylized model of the 1973-1974 oil market dynamics is consistent both with the absence of significant increases in the real price of oil and the observed increase in oil production in the early 1970s. It also is consistent with the fall in the quantity of oil produced and the sharp increase in the OPEC oil price in 1973-1974. The 1973-1974 episode illustrates the point that fundamental identification problems need to be addressed before we can assess the effect of exogenous political events in the Middle East on the price of oil. As we have shown, the observed price and quantity movements in 1973-1974 are consistent both with supply interruptions and with the restoration of equilibrium after the removal of price ceilings. Our model also is consistent with the views of oil economists such as Mabro (1998, p. 10) that "a major political crisis will not cause a price shock when capacity cushions exist in other coun- 
tries, while excess demand would cause prices to flare even in the absence of any political crisis."

The fact that the cumulative rise in the oil price did not exceed the cumulative increase in other industrial commodity prices suggests that the actual oil price in January 1974 was probably not far from the marketclearing level. As we will argue later, OPEC market power played a more important role in determining the price of oil only after January 1974, when OPEC attempted to stabilize the price of oil at its peak level, even as the U.S. economy slid into recession and other commodity prices fell sharply.

An alternative interpretation of the oil price increase of 1973-1974 has been proposed by Hamilton (1999). Hamilton stresses the role of oil supply interruptions that are exogenous to the state of the U.S. macroeconomy. He discusses several such supply interruptions that in his view were caused by "military conflicts" and "wars" [including (1) the October 1973 war, (2) the Iranian revolution of late 1978; (3) the outbreak of the Iran-Iraq war in September 1980, and (4) the Gulf war of 19901991]. There is some doubt, however, about the extent to which these events were truly exogenous. Hamilton is not explicit about the nature of the causal link from military conflict to exogenous production cutbacks. In some cases, for example in discussing the Gulf war (p. 28) or the Iraq-Iran war (in his Appendix B), he clearly has in mind the physical destruction of oil facilities and the war-induced disruption of oil shipping. ${ }^{25}$ In contrast, the production cutbacks in late 1973 clearly were not caused directly by military conflict. ${ }^{26}$ In fact, most of the production cutbacks occurred only after the war (which lasted from October 6 to October 23, 1973) as part of an oil embargo by Arab oil producers.

In his Appendix B, Hamilton postulates a causal link from the October war to this oil embargo. This link is questionable. Unlike the war itself, the oil embargo is not an exogenous political event. There is considerable evidence that oil producers carefully considered the economic feasibility of the oil embargo. ${ }^{27}$ In fact, the oil embargo was contemplated as early

25. Hamilton (1999, p. 28) refers to "a number of historical episodes in which military conflicts produce dramatic and unambiguous effects on the petroleum production from particular fields" such as the Iraqi invasion of Kuwait in July 1990.

26. During this war only Syrian and Iraqi oil facilities sustained battle damage. Neither country was a major oil producer, and the loss of oil output was small. The bulk of the reduction in oil output that did occur in late 1973 can be attributed to countries that were not directly involved in the war, but chose to restrict output, notably Saudi Arabia and Kuwait (see U.S. Energy Information Administration, 1994, p. 307).

27. An early example is King Faisal of Saudi Arabia's rejection in 1972 of the use of the oil weapon on economic grounds (see Terzian, 1985, p. 164). That decision was reversed in late 1973, when more than a third of U.S. oil consumption was accounted for by 
as July 1973, well before the October war (see Arad and Smernoff, 1975, p. 124), and United States officials were aware of that threat. ${ }^{28}$ Although some countries announced a first stage of production cuts as early as October 18 (in the last week of the war), the embargo was tightened only after hostilities had ended on October 23. Not surprisingly, the oil embargo was lifted without its original political goals being achieved, as soon as oil prices had reached a sufficiently high level. Concern for the Arab cause lasted only as long as it was economically expedient.

Moreover, contrary to popular perception (see the quotation from the Economist in Section 1), the oil embargo was not associated with a quadrupling of oil prices. In actuality, the price increase that coincided with the embargo was only half as large. The other half of the oil price increase occurred well before the embargo. In 1971, the basic structure of the contractual agreements between oil companies and OPEC countries had been renegotiated at conferences in Teheran and Tripoli. These agreements were long-term in nature. Neither the oil companies nor the OPEC governments anticipated the subsequent successive dollar devaluations in 1971 and 1973, the rapid rise in U.S. inflation, and the extraordinary surge in the demand for oil in 1972 and 1973. In response to these events, OPEC countries and oil companies repeatedly renegotiated the conditions of their contracts. Posted prices of light Arabian crude gradually rose from $\$ 2.29$ in June 1971 to $\$ 2.90$ in February 1973 .

In June 1973, pressure mounted to abandon the framework of Teheran and Tripoli and for governments to set posted prices unilaterally. By September 1973, all the OPEC countries were prepared formally to request a revision of the price agreements, as the gap between market prices and posted prices widened. Negotiations opened on October 8, two days after the outbreak of the October 1973 war. OPEC proposed to raise the price of oil to $\$ 5.12$. The oil companies stalled for time. On October 16, 1973, OPEC renounced the Teheran and Tripoli agreements and unilaterally adopted the proposal they had earlier put before the companies. As Penrose (1976, p. 50) notes, "the October 1973 increases

imports. Similarly, during the 1971 Teheran negotiations between the major oil companies, the Gulf states threatened to implement an oil embargo, but never implemented it. Again, during Israel's invasion of Lebanon in 1982-which coincided with high oil prices, a global recession, and high real interest rates-an oil embargo was considered by the Organization of Arab Petroleum Exporting Countries, but rejected as inconsistent with the economic interests of the organization (see Yergin, 1992, pp. 582, 719; Skeet, 1988, p. 187).

28. Arad and Smernoff (1975, p. 190) note that in July 1973 the Committee on Emergency Preparedness of the National Petroleum Council issued a report that concluded that an interruption of petroleum imports into the U.S. was likely as early as January 1974, based on data on the dependence of the U.S. on oil imports. 
in posted prices were not related to the war, but to the fact that the assumptions underlying the Teheran agreement had proved unjustified. The exporting countries therefore felt that the . . p prices agreed upon in Teheran required adjustment to the new market and monetary conditions. These conditions were not, in their view, of their own making, since they had not cut back supplies. . .." In fact, the quantity of oil supplied by OPEC had gradually increased from 29.9 million barrels per day in January 1973 to 32.7 million barrels per day in September 1973. Thus, as we showed earlier, not only are there strong reasons to doubt that the second doubling of oil prices on January 1, 1974, was caused by exogenous oil supply cuts, but there is overwhelming evidence that the initial doubling of the oil price to $\$ 5.12 /$ barrel was due to increased demand for oil.

\subsection{WHY DID THE 1979-1980 OIL PRICE INCREASE OCCUR WHEN IT DID?}

We now turn to the second major oil price increase of the 1970s, which took place in 1978-1980. As in the early 1970s, there is clear evidence of an output boom, unusually low real interest rates, and rising inflation prior to 1980. The rapid growth was fueled by the renewed world-wide monetary expansion documented in Section 4. Although this expansion was reflected in a sustained increase in industrial commodity prices in 1976-1979, the increase in other commodity prices was dwarfed by the increase in oil prices that started in late 1978 (see Figure 6). Since the surge in oil prices not only far exceeded inflation adjustments, but also was not supported by a corresponding tightening in other commodity markets, it must have reflected additional developments specific to the oil market. Judging by the increase in other industrial commodity prices in 1978-1979, at best one-third of the actual oil price increase appears to be consistent with the monetary model. In that respect, the second oil crisis appears fundamentally different from the first oil crisis of 1973-1974..$^{29}$

The inability of the monetary model to explain more than one-third of the oil price increase in 1979-1980 does not imply that the other twothirds of the increase was due to oil production cutbacks caused by the Iranian revolution in late 1978 and the outbreak of the Iran-Iraq war in September 1980, as suggested by Hamilton (1999). First, taking into

29. Also note that, unlike in 1973-1974 when oil prices doubled in a single day, the oil price increase in 1979-1980 was much more gradual. One reason is that-unlike in the early 1970s-OPEC oil prices had not been held back by what was effectively a price ceiling. Thus, the observed oil price dynamics cannot be explained by a disequilibrium adjustment of the kind described in Figure 7. 
account the offsetting production increases by other oil producers such as Saudi Arabia, the production shortfall in early 1979 was not nearly as dramatic as suggested by Hamilton (1999). Global production in October, November, and December 1978 exceeded the September 1978 level. Only in January and February of 1979, at the height of turmoil in Iran, did global oil production fall significantly below its September 1978 level, by $4 \%$ and $3 \%$, respectively (see U.S. Energy Information Administration, 1994, p. 312). ${ }^{30}$ Moreover, total annual OPEC oil production in 1979 was $4 \%$ higher than in 1978 (see Skeet, 1988, p. 244).

Second, the timing of the oil price increase suggests that physical production shortfalls narrowly defined are not the cause of the oil price surge. The bulk of the oil price increases occurred well after the Iranian revolution was over and well before the outbreak of the Iran-Iraq war. Specifically, during the Iranian revolution, between October 1978 and April 1979, the average price of U.S. oil imports rose by only about \$3/ barrel (see DRI database). In February 1979, Iran announced the resumption of exports, and by April 1979, global oil production matched the September 1978 level. The main surge in oil prices began only in May 1979, at a time when global oil production exceeded its September 1978 level (see U.S. Energy Information Administration, 1994, p. 312). Between May and October 1979 alone, oil prices rose from $\$ 19$ to $\$ 25$ per barrel. Oil prices continued to climb to almost $\$ 34$ by April 1980, when the armies of Iran and Iraq were first put on alert (see Terzian, 1985, p. 279). The war broke out in September 1980. In December 1980, oil was still under \$36. It finally rose to a peak of \$39 in February 1981.

One explanation of the additional oil price rise that occurred between mid-1979 and mid-1980 that has been proposed in the literature is a temporary surge in precautionary demand in response to increased uncertainty about future oil supplies and expectations of strong future demand (see Adelman, 1993, p. 428). The uncertainty-based explanation of higher oil prices, however, does not seem plausible in the absence of taut demand conditions in the oil market, which in turn were driven in no small measure by a booming world economy and low real interest rates. The fact that a large number of military conflicts and incidents in the Gulf region in subsequent years did not lead to sustained increases in oil prices suggests that increased Middle East uncertainty appears to have little or no effect on oil prices in the absence of favorable macro-

30. Hamilton notes that Iranian cutbacks in January and February 1979 amounted to almost $9 \%$ of the average monthly global oil production for 1978 . Using the same data source, after allowing for production increases elsewhere, global oil production in January and February 1979 actually matched or exceeded slightly the average 1978 level (see U.S. Energy Information Administration, 1994, p. 312). 
economic conditions. ${ }^{31}$ It is no coincidence that oil prices (as well as nonoil commodity prices) peaked shortly after Paul Volcker launched a sharp monetary contraction resulting in a global recession and high real interest rates.

Weakening demand played a crucial role in undermining Saudi Arabia's efforts to shore up the oil price between 1982 and 1985 by reducing oil supply. The fact that other OPEC members undercut the official OPEC price in 1982-1985 appears consistent with the view that, in the absence of effective monitoring and punishment, cash-starved oil-producing countries (such as Iraq and Iran) had an incentive to undercut the cartel price in order to increase current revenue. At the same time, competition from other oil producers increased. By the early 1980s, a large number of new oil suppliers such as Egypt, Angola, Malaysia, China, Norway, and the United Kingdom had entered the market in response to the unusually high oil prices of the 1970s, while existing producers including the United States (Alaska), Mexico, and the USSR had invested in new capacity and expanded oil production. By 1982, less than half of world oil was supplied by OPEC, compared with two-thirds in 1977 (see Skeet, 1988, p. 201). The resulting downward pressure on oil prices is consistent with the predictions of the Hotelling model with capacity constraints.

We do not attempt to address in this paper the reasons for the long delay in the decline of oil prices-both in the mid-1970s and in the early 1980 s - after the initial monetary expansion was reversed. Although the sharp oil price increases in the 1970s came on the heels of shifts in the demand for oil that-in our view-were directly or indirectly fueled by monetary expansion, OPEC seems to have been adept at restraining official price cutting even in the presence of significant excess capacity. Figure 8 shows that other industrial commodity prices dropped sharply in response to recessions and higher real interest rates, as theory would suggest. Oil prices, however, remained at a much higher level than

31. Examples include the Israeli attack on an Iraqi nuclear reactor in June 1981; a state of near-war between Israel and Syria from April to July 1981 (see Skeet, 1988, p. 181); the invasion of Lebanon by Israel in June 1982; the Iranian Ramadan offensive against Iraq in July 1982 (see Yergin, 1992, p. 764); Iran's threat in July 1983 to blockade the Straits of Hormuz (see Terzian, 1985, p. 323); suicide attacks on the U.S. and French headquarters in Lebanon in October 1983 (see Skeet 1988, p. 197); the tanker war in the Gulf in February-April 1984, during which at least eleven tankers and the major Iranian oil terminal were hit (see Terzian, 1985, p. 327; Yergin, 1992, p. 743); the Iranian capture of the Fao Peninsula in the southeastern corner of Iraq in February 1986, followed by Iranian artillery and missile attacks on Kuwait's oil ports and Iranian naval attacks on Kuwaiti shipping; the Kuwaiti request for U.S. naval patrols in the Gulf in March 1987 to protect its oil tankers (see Yergin, 1992, p. 765); the Iraqi missile attack on the U.S.S. Stark during the tanker war in May 1987, resulting in the deaths of 36 sailors; and the downing of an Iranian airliner by U.S. forces in the Gulf in July 1988 following skirmishes with Iranian patrols (see Yergin, 1992, p. 766). 
other commodity prices during 1974-1978 and again during 1981-1985. This differential response after the onset of the 1974-1975 and 1981-1982 recessions is suggestive of the use of OPEC market power to prop up oil prices. As Nordhaus (1980, p. 367) notes, in periods of excess demand, there is little OPEC can do (or would want to do) to impede oil price increases. Once official OPEC prices have risen, however, they tend to be sticky, even when there is a glut in the oil market. Indeed, empirical and anecdotal evidence lends support to the view that OPEC was most influential not in 1973-1974 or in 1979 during the time of the most rapid oil price increases - as popular opinion would suggest-but in preventing oil prices from falling as rapidly as they should have when oil demand subsided (also see Mabro, 1998, pp. 10-11).

\section{Lessons from the Most Recent Oil Price Surge}

The tripling of oil prices after 1998 provides us with yet another opportunity to test the implications of our explanation of stagflation. Historically, as we have shown in Section 6, oil price increases by themselves have caused excess CPI inflation (relative to inflation in the GDP deflator) for short periods, rather than extended periods of inflation. The current episode is no exception. U.S. data after 1998 show a spike in CPI inflation relative to deflator inflation rates (see Figure 8 ). In contrast, there has been little movement in the inflation rate of the deflator. This finding is not surprising, because there has not been a major monetary expansion of the kind that was characteristic of the 1970s. Also noteworthy is the fact that, despite higher oil prices, there is no evidence yet of a major contraction, which seems to belie the notion that oil price increases inevitably cause recessions.

Although real interest rates have not been unusually low, cumulative growth rates for the United States have been extraordinarily high-high enough to offset the less than stellar growth performance of Europe and Japan. That increase in output, however, appears to be different from the rapid output growth in the 1970s that was largely fueled by monetary expansion. The very strong real growth in the past several years, especially in the U.S., has been reflective of an increase of potential output rather than "demand" generated (see Basu, Fernald, and Shapiro, 2000). Our analysis suggests that this strong growth in output was instrumental in supporting the increase in oil prices in 1999-2000. If the United States had been in a recession during 1999-2000 and U.S. demand for oil had been low, it would have been hard for OPEC to enforce high oil prices over extended periods. The ability of a cartel like OPEC to sustain prices above the competitive level depends on a conducive macroeconomic environment. If there is a significant contraction of 
the economy, historical experience suggests that OPEC will have an uphill battle maintaining the current level of oil prices.

Both oil and other commodity prices fell sharply after the Asian crisis, yet only oil prices have strongly rebounded. This discrepancy is suggestive of a larger role for OPEC after 1998 than in earlier episodes. One interpretation we can rule out for sure is that OPEC has been reacting to exogenous political events in the Middle East. Certainly, the latest major oil price increase was not preceded by physical production cutbacks "induced by war" along the lines of Hamilton (1999). In fact, oil prices rose during the period of peace making between Israel and the Palestinians, but Arab leaders refused to use the "oil weapon" when the recent confrontations erupted (see Washington Post, 2000). This is not surprising, given the already high level of oil prices, and certainly is consistent with our view that in previous episodes political factors were allowed to play a role in setting oil prices only to the extent that they did not conflict with economic objectives and constraints.

What then enabled OPEC to consolidate its power after its influence had declined ever since the late 1980s? There are two reasons. One is that other oil producers (such as Norway and Mexico) that are not part of OPEC effectively joined forces with OPEC, raising the organization's effective market share, which had declined dramatically in the 1980s (see New York Times, 2001). The consolidation of OPEC is consistent with theoretical models of cartels, such as Green and Porter (1984), that lead us to expect that cartels will flourish in periods of strong economic growth. Second, there is evidence that oil producers across the world, with the possible exception of Saudi Arabia, were once again operating close to capacity, and that few additional oil supplies were likely to be forthcoming in the short run. This scarcity was arguably driven in important part by strong demand for crude oil. The rise in oil prices coincided with a shortage of oil tankers, and freight rates for crude oil shipments have increased sharply, suggesting high demand for oil. Thus, the problem appears to have been one of insufficient inventories in the face of rapidly rising demand for oil, rather than a global supply cut.

This view is further supported by the sharp drop of crude-oil prices in late December 2000 from a peak of more than \$37 per barrel to below \$27 upon news reports of an impending U.S. recession, despite low inventories, Middle East turmoil, one of the coldest winters in recent memory, and the high likelihood that most of Iraq's oil exports would remain off global markets. Predictably, OPEC will attempt to stem the expected decline in oil prices by announcing production cutbacks, as it did after each of the major oil price increases in the 1970s when demand for oil began to slacken (see New York Times, 2001). How long OPEC will be able to sustain high real oil prices will depend on the depth of the economic 
downturn as well as the extent to which new non-OPEC oil supplies will be forthcoming in response to higher oil prices.

\section{Concluding Remarks}

The origins of stagflation and the possibility of its recurrence continue to be an important concern among policymakers and in the popular press. Our analysis suggests that in substantial part the Great Stagflation of the 1970s could have been avoided, had the Fed not permitted major monetary expansions in the early 1970s. We demonstrated that the stagflation observed in the 1970s is unlikely to have been caused by supply disturbances such as oil shocks. This point is important, because to the extent that stagflation is due to exogenous supply shocks, any attempt to lower inflation would worsen the recession. In contrast, if we are right that stagflation is first and foremost a monetary phenomenon, then stagflation does not present an inevitable "policy dilemma." We conclude that oil price increases by themselves are unlikely to reignite stagflation, as long as the Federal Reserve refrains from excessively expansionary monetary policies. Moreover, a sustained increase in the real price of oil is unlikely in the absence of a conducive macroeconomic environment in OECD countries.

\section{REFERENCES}

Abel, A., and B. Bernanke. (1998). Macroeconomics, 3rd ed. Reading, MA: Addison-Wesley.

Adelman, M. A. (1993). The Economics of Petroleum Supply. Cambridge, MA: The MIT Press.

Arad, U. B., and B. J. Smernoff. (1975). American Security and the International Energy Situation. New York: Hudson Institute.

Barro, R. J. (1987). Macroeconomics, 2nd ed. New York: Wiley.

rate model. Journal of Political Economy 91:589-610.

Basu, S., J. Fernald, and M. D. Shapiro. (2000). Productivity growth in the 1990s: Technology, utilization or adjustment? Department of Economics, University of Michigan. Mimeo.

Bernanke, B. S. (1983). Irreversibility, uncertainty, and cyclical investment. Quarterly Journal of Economics 98:85-106.

tary policy transmission. Journal of Economic Perspectives 9:27-48.

- - and M. W. Watson. (1997). Systematic monetary policy and the effects of oil price shocks (with discussion). Brookings Papers on Economic Activity 1:91-148.

— , and I. Mihov. (1998). Measuring Monetary Policy. Quarterly Journal of Economics 113(3):869-902.

Berndt, E.-R., I. M. Cockburn, and Z. Griliches. (1996). Pharmaceutical innovations and market dynamics: Tracing effects on price indexes for antidepressant drugs. Brookings Papers on Economic Activity: Microeconomics 133-188. 
Blinder, A. (1979). Economic Policy and the Great Stagflation. New York: Academic Press.

Bohi, D. R. (1989). Energy Price Shocks and Macroeconomic Performance. Washington: Resources for the Future.

Bordo, M. D., and B. Eichengreen. (1993). A Retrospective on the Bretton Woods System: Lessons for International Monetary Reform. NBER project report. Chicago: University of Chicago Press.

— nism. In Modern Perspectives on the Gold Standard, T. Bayoumi, B. Eichengreen, and M. P. Taylor (eds.). Cambridge: Cambridge University Press, pp. 55-100.

Boschen, J. F., and L. O. Mills. (1995). The relation between narrative and money market indicators of monetary policy. Economic Inquiry 33(1):24-44.

Bruno, M., and J. Sachs. (1985). Economics of Worldwide Stagflation. Cambridge, MA: Harvard University Press.

Burns, A. F. (1978). Reflections of an Economic Policy Maker. Speeches, and Congressional Statements: 1969-1978. Washington: American Enterprise Institute for Public Policy Research.

Cagan, P. (1979). Persistent Inflation: Historical and Policy Essays. New York: Columbia University Press.

Calvo, G. (1983). Staggered prices in a utility-maximizing setting. Journal of Monetary Economics 12(3):383-398.

Christiano, L. J., M. Eichenbaum, and C. L. Evans. (1996). The effects of monetary policy shocks: Some evidence from the flow of funds. Review of Economics and Statistics 78:16-34.

- , and C. Gust. (2000). The expectations trap hypothesis. International Finance Discussion Paper No. 676. Board of Governors of the Federal Reserve.

Clarida, R., J. Galí, and M. Gertler. (2000). Monetary policy rules and macroeconomic stability: Evidence and some theory. Quarterly Journal of Economics 115:147-180.

Darmstadter, J., and H. H. Landsberg. (1976). The economic background. In The Oil Crisis, R. Vernon (ed.). New York: Norton.

De Long, B. J. (1997). America's peacetime inflation: The 1970s. In Reducing Inflation: Motivation and Strategy, C. Romer and D. Romer (eds.). Chicago: University of Chicago Press.

Economist. (1999). “Oil's Pleasant Surprise." November 27, p. 16.

Fisher, I. (1906). The Rate of Interest. New York: MacMillan.

Friedman, M. (1975). Perspectives on Inflation. Newsweek, June 24, p. 73.

Genberg, H., and A. K. Swoboda. (1993). The provision of liquidity in the Bretton Woods system. In A Retrospective on the Bretton Woods System: Lessons for International Monetary Reform, M. D. Bordo and B. Eichengreen (eds.). NBER project report. Chicago: University of Chicago Press, pp. 269-315.

Gordon, R. J. (1984). Supply shocks and monetary policy revisited. American Economic Review, 74:38-43.

Green, E. J., and R. H. Porter. (1984). Noncooperative collusion under imperfect price information. Econometrica, 52(1):87-100.

Griliches, Z., and I. Cockburn. (1994). Generics and new goods in pharmaceutical price indexes. American Economic Review, 84(5):1213-1232.

Hamilton, J. D. (1983). Oil and the macroeconomy since World War II. Journal of Political Economy 91:228-248.

Journal 6:97-115. 
(1988). A neoclassical model of unemployment and the business cycle. Journal of Political Economy 96:593-617.

. (1999). What is an Oil Shock? Cambridge, MA: National Bureau of Economic Research. NBER Working Paper 7755.

Hetzel, R. L. (1998). Arthur Burns and inflation. Federal Reserve Bank of Richmond Economic Quarterly 84:21-44.

Heal, G., and G. Chichilnisky. (1991). Oil and the International Economy. Oxford: Clarendon Press.

Holland, S. (1998). Existence of competitive equilibrium in the Hotelling model with capacity constraints. Department of Economics, University of Michigan. Mimeo.

Hotelling, H. (1931). The economics of exhaustible resources. In Microeconomics: Theoretical and Applied, Vol. 1. R. E. Kuenne (ed.). Aldershot: Elgar, 1991, pp. 356-394.

Houthakker, H. (1987). The ups and downs of oil. In Deficits, Taxes, and Economic Adjustments, P. Cagan (ed.). Washington: American Enterprise Institute.

International Monetary Fund. International Financial Statistics, various issues.

Kimball, M. S. (1995). The quantitative analytics of the basic neomonetarist model. Journal of Money, Credit, and Banking 27(4), Part 2: 1241-1277.

King, R., and M. Goodfriend. (1997). The new neoclassical synthesis and the role of monetary policy. In NBER Macroeconomics Annual, No. 12. B. S. Bernanke and J.-J. Rotemberg (eds.). Cambridge, MA: MIT Press.

Kydland, F. E., and E. C. Prescott. (1977). Rules rather than discretion: The inconsistency of optimal plans. Journal of Political Economy 85:473-492.

Leeper, E. M. (1997). Narrative and VAR approaches to monetary policy: Common identification problems. Journal of Monetary Economics 40(3):641-657.

Lucas, R. E. (1972). Expectations and the neutrality of money. Journal of Economic Theory 4:103-124.

- (1973). Some international evidence on output-inflation tradeoffs. American Economic Review 63:326-334.

Mabro, R. (1998). OPEC behavior 1960-1998: A review of the literature. The Journal of Energy Literature 4:3-27.

McKie, J. W. (1976). The United States. In The Oil Crisis, R. Vernon (ed.). New York: Norton.

McKinnon, R. I. (1982). Currency substitution and instability in the world dollar standard. American Economic Review 72(3):320-333.

Mundell, R. A. (2000). A reconsideration of the twentieth century. American Economic Review 90(3):327-340.

National Commission on Supplies and Shortages. (1976). The Commodity Shortages of 1973-1974. Case Studies. Washington: U.S. Government Printing Office.

Nelson, E. (1998). Sluggish inflation and optimizing models of the business cycle. Journal of Monetary Economics 42:303-322.

New York Times. (2001). For OPEC, cuts in production are a delicate balancing act. January 11, p. 1.

Nordhaus, W. D. (1980). Oil and economic performance in industrial countries. Brookings Papers on Economic Activity 2:341-388.

Orphanides, A. (2000). Activist stabilization policy and inflation: The Taylor rule in the 1970s. Board of Governors of the Federal Reserve. Discussion Paper.

—, R. D. Porter, D. Reifschneider, R. Tetlow, and F. Finan. (1999). Errors in 
the measurement of the output gap and the design of monetary policy. Board of Governors of the Federal Reserve. Discussion Paper.

Penrose, E. (1976). The development of crisis. In The Oil Crisis, R. Vernon (ed.). New York: Norton.

Roberts, S. (1984). Who Makes the Oil Price? An Analysis of Oil Price Movements 1978-1982. Oxford: Oxford Institute for Energy Studies.

Rogoff, K. (1985). The optimal degree of commitment to an intermediate monetary target. Quarterly Journal of Economics 100:1169-1190.

Rotemberg, J. (1982). Sticky prices in the United States. Journal of Political Economy 90(6):1187-1211.

- (1996). Prices, output, and hours: An empirical analysis based on a sticky price model. Journal of Monetary Economics 37(3):505-533.

- and G. Saloner. (1986). A supergame-theoretic model of business cycles and price wars during booms. American Economic Review 76:390-407.

ergy price increases on economic activity. Journal of Money, Credit, and Banking 28(4), Part 1: 550-577.

Samuelson, P. A. (1974). Worldwide stagflation. In Collected Scientific Papers, Vol. 4. H. Nagatani and K. Crowley (eds.). Cambridge, MA: The M.I.T. Press, 1977.

- , and R. M. Solow. (1960). Analytical aspects of anti-inflation policy. American Economic Review 40(2):177-194.

Sargent, T. J. (1998). The Conquest of American Inflation. Hoover Institution.

Seymour, I. (1980). OPEC: Instrument of Change. London: Macmillan.

Skeet, I. (1988). OPEC: Twenty-Five Years of Prices and Politics. Cambridge: Cambridge University Press.

Taylor, J. (1979). Staggered wage setting in a macro model. American Economic Review 69(2):108-113.

Terzian. P. (1985). OPEC: The Inside Story. London: Zed Books.

United States Energy Information Administration. (1994). Historical Monthly Energy Review: 1973-1992. U.S. Government Printing Office.

Washington Post. (2000). Arab leaders meet for summit. October 21.

Yergin, D. (1992). The Prize. The Epic Quest for Oil, Money, and Power. New York: Simon and Schuster.

\section{Comment}

OLIVIER BLANCHARD

Massachusetts Institute of Technology

\section{Introduction}

Revisionist history is always fun. But it is not always convincing. I have enjoyed thinking about the thesis developed by Barsky and Kilian. But I am not convinced. 


\section{The Noncontroversial Part: The Role of Money in the Early 1970s}

Not all of the paper is revisionist; indeed, some of it is less so than it sounds: There is, I believe, wide agreement that money played a major part in what happened in the early to mid-1970s. Most observers would in particular agree to the following propositions (much of what follows can, for example, be found in the book by Michael Bruno and Jeffrey Sachs on the Economics of Stagflation, published in 1985):

Expansionary monetary policy was an important factor in stimulating growth and reducing unemployment in the United States after the 1970 recession. By 1973, the unemployment rate was $4.9 \%$, down from $6.0 \%$ in 1971 .

U.S. inflation came down until 1972, and then started increasing in 1973, suggesting that the unemployment rate was then close to the natural rate. It is therefore likely that, had the output expansion continued at the same rate after 1973, inflation would have further increased, even absent any changes in the relative price of oil.

Expansionary monetary policy in the United States, and the attempts by foreign central banks to maintain the value of the dollar, led to large induced monetary expansions abroad. Growth in the other major OECD countries-countries, which in contrast to the United States, had not had a recession in 1970continued to be high. Unemployment continued to be very low. Inflation in the EEC steadily increased, nearly doubling between 1970 and 1973. There again, a slowdown in activity was clearly needed, and would have come, even absent the increase in the price of oil.

This world monetary expansion was associated with low nominal interest rates, and even lower real interest rates. This, combined with strong world demand, was more than enough to trigger an increase in the price of commodities and raw materials some time before the increase in the price of oil.

In short, even absent the increase in the price of oil, 1974 and 1975 would have seen either increasing inflation and/or a slowdown in growth. Most likely, given the attitude of central banks from 1973 on, the outcome would have involved monetary tightening and a slowdown in growth.

\section{Controversial Point 1: One Can Explain Stagflation within a Model with Only Monetary Shocks}

Let me start with what looks like a semantic issue, but is in fact more. 
Barsky and Kilian define "stagflation" as the coincidence of "low or negative output growth" and "high inflation" (i.e., $\Delta u>0, \pi$ high). They arguerightly - that this is easy to generate in a model with nominal rigidities. In effect, we know that inflation builds up slowly after a monetary expansion. At some point, high inflation leads to a decrease in real money, which in turn leads to a decrease in output growth; at that point there is indeed high inflation and low, possibly negative, output growth.

A more conventional definition of "stagflation" however is the coincidence of high unemployment and increasing inflation (i.e., u high, and $\Delta \pi>0$.

Why does this semantic discussion matter? Because (1) what was observed in the 1970s was indeed a combination of high unemployment and increasing inflation, i.e. stagflation according to the second definition; (2) this combination is very hard to generate in response to only changes in money growth. Let me develop both points.

On the empirical evidence: The average unemployment rate from 1973 to 1975 was $6.4 \%$, substantially higher than what the natural rate of unemployment had been until then. And, over the same period, the increase in inflation was around 5 percentage points. The period was one of high unemployment and increasing inflation.

On the theoretical proposition: Go back to a conventional Phillipscurve relation:

$$
\pi_{t}-\pi_{t}^{e}=-a\left(u_{t}-\bar{u}\right) .
$$

Inflation minus expected inflation is a decreasing function of the distance between the actual unemployment rate and the natural unemployment rate. In the absence of supply shocks, $\bar{u}$ is a constant.

Stagflation (according to the second definition, and the 1973-1975 facts) implies the coincidence of increasing inflation, viz.

$$
\pi_{t}-\pi_{t-1}>0
$$

and of unemployment above the natural rate, viz. $u_{t}-\bar{u}>0$, so that, by implication,

$$
\pi_{t}-\pi_{t}^{e}<0
$$

These two conditions can be rewritten as

$$
\pi_{t}^{e}-\pi_{t-1}>\pi_{t}-\pi_{t-1}>0 \text {. }
$$


In words, the expected increase in inflation must exceed the actual increase in inflation, and this at a time at which inflation is increasing. It is difficult to think of expectation formation mechanisms which will naturally deliver this result. The learning model presented by Barsky and Kilian does not. In general, learning does not seem promising here: It seems more likely to lead to the opposite inequality, with the expected increase in inflation lagging behind the actual increase.

So, how can one generate stagflation? By having an increase in the natural rate $\bar{u}$, or, equivalently for our purposes, a positive disturbance to the Phillips-curve relation. A natural candidate is an increase in the price of oil, which generates an increase in $\bar{u}$, or, equivalently for our purposes, a positive disturbance in the Phillips-curve relation. Thus, the traditional focus on supply shocks to explain the 1970s.

This argument however suggests one way out for proponents of the monetary-policy explanation. Barsky and Kilian do not push it explicitly, but clearly they could, as it is in the spirit of their paper. If expansionary monetary policy leads to an increase in the relative price of oil, then one indeed can in principle generate stagflation just from monetary shocks. This leads to the second major issue, the degree to which one can think of the large increases in the price of oil in the 1970s as endogenous and triggered by monetary policy.

\section{Controversial Point 2: The Increase in the Price of Oil in the 1970s Was an Endogenous Response to a Money-Driven World Boom}

Here, theory is on the side of Barsky and Kilian. Oil is a natural resource. Current or anticipated increases in demand or decreases in the real interest rate should both lead to an increase in the current price. And, indeed, the early 1970s were a period of high demand and low real rates.

The problem is empirical. I am no expert on the oil market. But from my reading of the literature, I have the strong feeling that most experts agree: The two increases in the price of oil were not the natural, if delayed, response to demand and interest rates, but were mostly the result of successful cartelization.

Agreement among experts is surely no proof. But the hypothesis of endogenous increase in the price of oil runs into a number of obvious problems (my - very limited-knowledge on these issues is largely based on M. A. Adelman's writings, in particular Adelman, 1993):

The degree to which the price of a good depends on the interest rate depends on the degree to which it is a fixed rather than a renewable resource. And here, the 
evidence seems to be that oil behaves more like the second than the first. The amount of so-called "proven resources" has consistently increased over time, despite the steady extraction of oil from the ground.

The degree to which the price depends on current and anticipated demand depends on the slope of the marginal-cost curve, relating the cost of extraction to the flow of extraction. Evidence suggests that, in the 1970s, the marginal-cost curve was rather flat: that there were a large number of fields from which oil could be extracted at close to the same cost per barrel-a cost far below the price which prevailed from 1974 on.

The increase in prices in the mid-1970s was associated with a decrease in production-not what you would expect to see in response to a shift in demand. The issue is taken up by Barsky and Kilian, who provide a creative, if not totally convincing, answer. But there is another empirical problem along the same lines: The increase in prices in the mid-1970s was associated with a decrease in production for the low-cost OPEC countries, and an increase in the production for the high-cost non-OPEC countries. This is hard to explain without giving some central role to OPEC in the story.

With the world recession of the mid-1970s, the high-demand conditions, which might have justified the high price of oil earlier, largely vanished. And later on in the decade, tighter monetary policy led to much higher real rates. Yet the price of oil remained high. The paper-and the literature-invoke "ratchet effects" (in the form of higher excise taxes, imposed by the oil-producing countries on oil companies); but this begs the question: Why not invoke the same mechanisms for the initial increase in the price of oil?

\section{Controversial Point 3: The Recession of the Mid-1970s Was Due to a Contraction in Money}

Here, the problem is again empirical and obvious. The way monetary contraction is supposed to work is through high interest rates. Nominal interest rates increased substantially in 1974 and 1975. This is shown in Figure 1, which plots short-, medium-, and long-term interest rates from the mid-1960s to the early 1990s. But inflation increased by more, and, based on forecasts of inflation at the time, so did expected inflation. This is shown in Figure 2, which plots short-, medium-, and long-term real interest rates, using inflation forecasts of the time, for the same period. Real interest rates were lowest in 1974 and 1975; indeed, in both years, the short real rate was negative, the longer real rates very close to zero. (The numbers are taken from Blanchard, 1993; the construction of the real rates is described in that paper.)

Can the monetary-contraction story survive Figure 2? Yes, if there is a role for the nominal interest rate, for a given real interest rate. And, 
$188 \cdot$ BLANCHARD

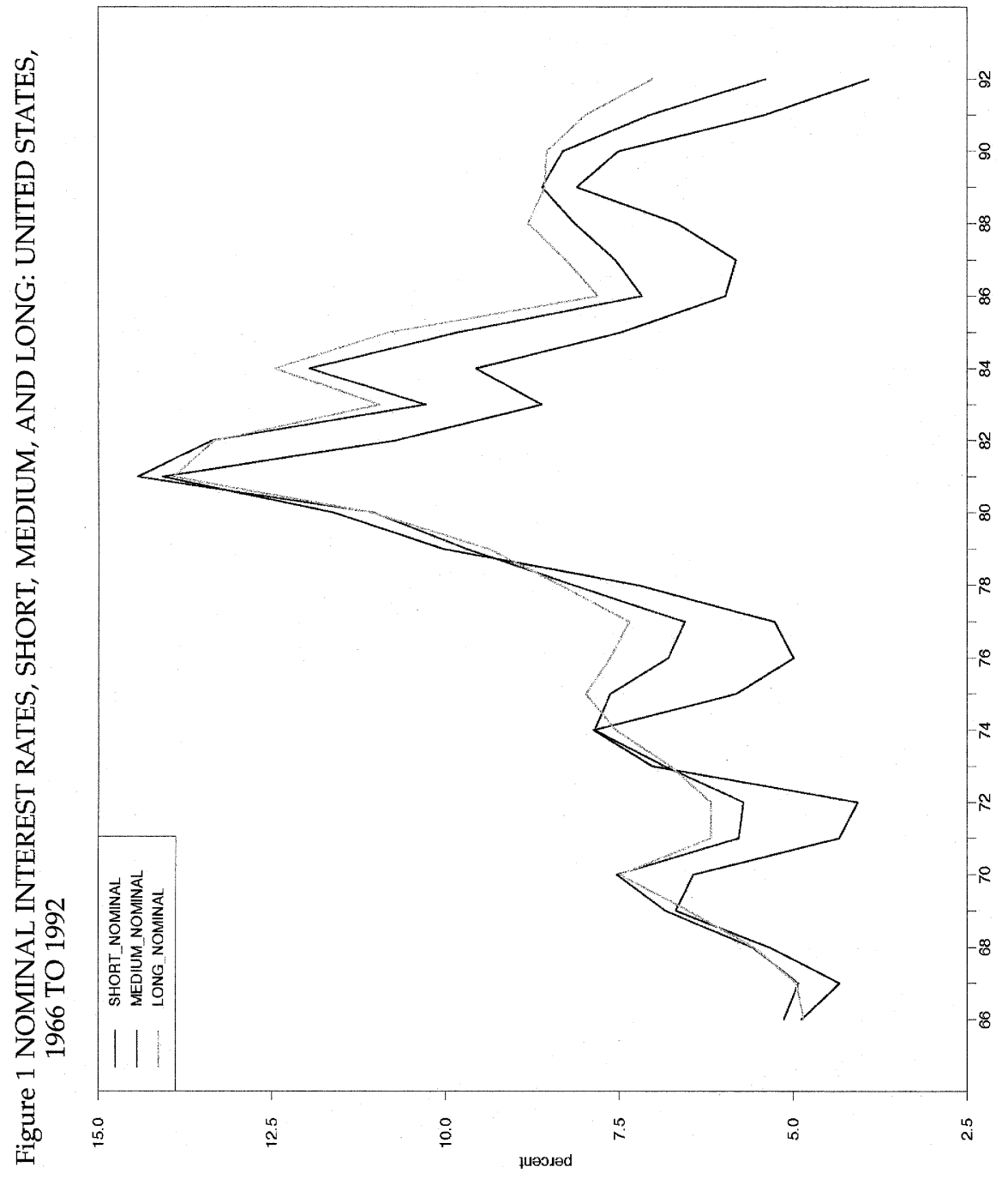


Comment 189

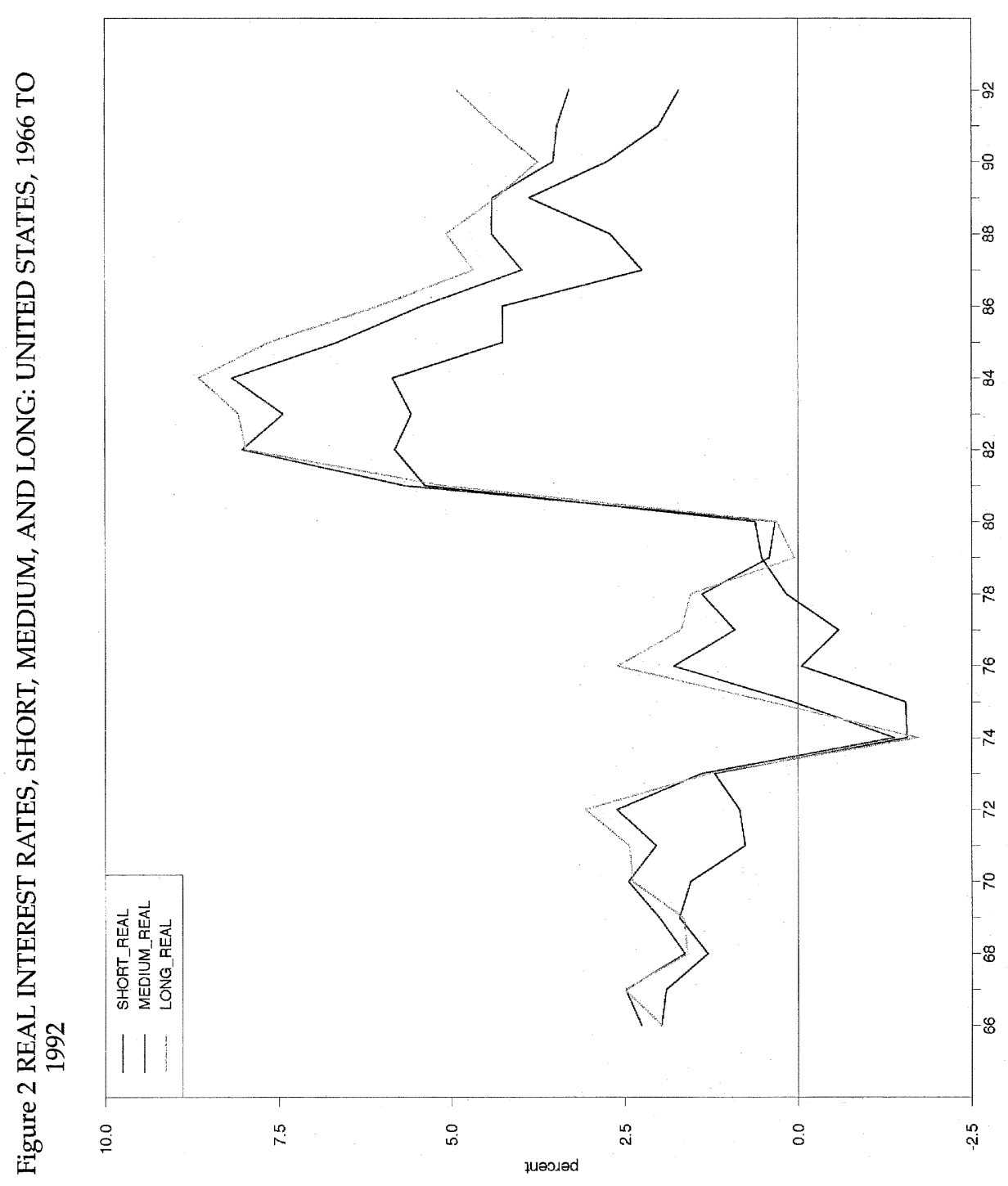


based on the research on the interaction between inflation, taxation, and intermediation, we can think of a number of channels through which nominal rather than real rates might matter. One may however doubt that the rather modest increase in nominal rates could have been enough to offset the effects of low real rates and generate a recession of the size observed in the mid-1970s. The burden of proof is on the authors on this one.

\section{Controversial Point 4: An Increase in the Price of Oil}

Should Have No Effect on the GDP Deflator; Yet the GDP Deflator Increased Substantially in the Mid-1970s

The argument that the price of oil should not affect the price of value added-the GDP deflator-is perfectly valid as far as it goes, that is, in partial equilibrium. The general-equilibrium closure offered by Barsky and Kilian, with fixed nominal money and fixed employment, is not convincing. Once one uses a more standard macroeconomic closure, the evidence on inflation appears quite consistent with theory.

Let me use the standard toy model here. Assume that consumers consume a bundle composed of a produced good and energy. The produced good is produced using labor. Denote by $p_{v}$ the $(\log )$ price of the produced good (the GDP deflator), by $x$ the (log) relative price of energy, and by $p$ the (log) consumption price index (the CPI). Then assume

$$
\begin{aligned}
& p=(1-\theta) p_{v}+\theta(p+x) \\
& p_{v}=w \\
& w=\alpha p+(1-\alpha) p(-1)+a y \\
& y=m-p \\
& m=b p, \quad b \leq 1 .
\end{aligned}
$$

The first equation states that the consumption price index is a weighted average of the price of the produced good and the price of energy, with $\theta$ as the share of energy in consumption. The second states that the price of the produced good is equal to the nominal wage (the constant terms are unimportant here, so I set them equal to zero).

The third equation states that the consumption wage depends on the output gap $y$. It introduces nominal wage rigidity in the form of a dependence of the wage on both the current and the lagged consumer price index. The fourth equation is a reduced-form aggregate demand equation giving the demand for the produced good as a function of real money balances. The last equation is a money rule. 
Solving the model is straightforward. For simplicity, let me just look here at the limit case where $b=1$, so there is full accommodation by the central bank, and $y$ remains constant (the difference with Barsky and Kilian is that constancy of output is the result of monetary accommodation, so the nominal money stock is not constant but endogenous). In this case, inflation is given by

$$
\begin{aligned}
\Delta p & =\frac{\theta x}{(1-\theta)(1-\alpha)}, \\
\Delta p_{v} & =\Delta w=\alpha \Delta p+(1-\alpha) \Delta p(-1) .
\end{aligned}
$$

Then:

An increase in the relative price of energy leads to positive inflation, measured using either the CPI or the GDP deflator.

Even if the share of energy in consumption is small, the effect of the relative price increase on inflation can be large. (For example, if $\theta=0.05$ and $\alpha=0.5$, then a $50 \%$ increase in the relative price of energy leads to an increase in inflation of $5 \%$.)

Inflation measured using the GDP deflator lags inflation measured using the CPI.

This is very much what was observed in the mid-1970s. The mechanism behind the increase in inflation is straightforward. Given the wage, the increase in the price of oil increases the CPI. But the implied decrease in consumption wages leads workers to ask for an increase in nominal wages, which leads in turn to an increase in the GDP deflator. Under the convenient assumption of full accommodation made here, inflation goes on forever. Under the more realistic assumption of partial accommodation, lower output eventually puts an end to these price and wage increases, and inflation eventually stops. But the results that inflation lasts for some time, it can be quite large relative to the shock, and CPI inflation leads inflation using the GDP deflator all remain.

\section{Conclusions}

I have argued that money cannot be the main culprit for what happened in the mid-1970s. It cannot explain stagflation. The behavior of interest rates does not fit. And most of the movements in the price of oil had little to do with monetary policy. 
Does this mean that there are no mysteries left? The answer is an emphatic no. There is plenty we do not understand about what happened in the 1970s, and more generally about the price of oil and economic activity. The list of puzzles is well known, from the surprising finding by Hamilton that most U.S. postwar recessions have been preceded by an increase in the price of oil (a finding which may turn to be true once more in the near future), to the apparent asymmetry between the effects of increases and decreases in the price of oil, to the sheer size of the two recessions of the 1970s. I thank the two authors for putting the issues back on the research agenda.

\section{REFERENCES}

Adelman, M. (1993). The Economics of Petroleum Supply. Cambridge, MA: The MIT Press.

Blanchard, O. (1993). The equity premium. Brookings Papers on Economic Activity 2:75-138.

\section{Comment}

ALAN S. BLINDER

Princeton University

This is a fascinating paper, one which is well worth reading. It more than repays the time you spend digesting it. It was also, obviously, meant to be a provocative paper, and I was, appropriately, provoked. In my book Economic Policy and the Great Stagflation (Blinder, 1979), which I dusted off to prepare this comment, I considered the monetary (dare I say "monetarist"?) explanation of the episode and concluded as follows: "If I were forced to summarize the influence of the Fed on the Great Stagflation, I guess I would stress how little difference it made rather than how much." Barsky and Kilian reach a rather different conclusion. Why? Was I so wrong in 1979?

Frankly, I find very few errors of commission in the paper. So the hunt must be for errors of omission. The paper reads a bit like a selective legal brief prepared by a pair of clever trial lawyers. So I'll try to add a few arguments for the defense (of the conventional wisdom) and point out that some of the conclusions that they portray as contrary to that wisdom are actually quite well known.

Leaving out many interesting details, their argument comes in five parts, and I'll take each up in turn. 
1. A PURELY MONETARIST MODEL OF GO-STOP POLICY GIVES A GOOD EXPLANATION OF THE STAGFLATIONARY EVENTS OF THE 1970s.

The authors indeed demonstrate that they can calibrate a relatively simple model of go-stop monetary policy that matches the cyclical facts without ever mentioning oil prices. Or can they? When I read, in the last paragraph of Section 3, of a predicted "output trough in early 1987" that "closely mirrors" the facts, I wondered what facts those were. I never noticed a 1987 trough, and neither did the NBER dating committee.

Incidentally, the model doesn't even need the "stop" part of "go-stop" to generate stagflation. As we have all known for years, the "go" part alone is enough. In a textbook aggregate-demand-aggregate-supply diagram, if a burst of demand growth (it need not be generated by money) leads the economy to overshoot its potential output, the adjustment back to equilibrium will entail both falling output and rising prices. Or, moving up a derivative to the Phillips-curve diagram, overshooting the natural rate will lead to an adjustment period in which both unemployment and inflation are rising at the same time. Many of us have demonstrated this well-known conclusion to our Economics 101 students-without using difference equations. ${ }^{1}$

\section{THERE IS ABUNDANT EVIDENCE IN FAVOR OF THE MONETARY EXPLANATION.}

It is one thing to claim that a certain type of model can explain a phenomenon; it is quite another to claim that the proffered explanation is empirically relevant. So Barsky and Kilian marshal a variety of empirical support for their monetary explanation of stagflation. But I am not entirely convinced.

For example, they show that several bursts of money growth occurred at approximately the right times to set off go-stop (or just go-adjust) cycles. But they never mention the (often simultaneous and offsetting) shifts of velocity - the very things that eventually led almost all economists and policymakers to abandon monetarism. One example comes in 1970 and 1971, when sharp declines in velocity seemed to validate Arthur Burns's perspicacious (or was it lucky?) prediction that falling velocity would obviate most of the dangers of rapid money growth. A second example is the apparent downward shift of the conventional money demand equation in 1974-1976, which Steve Goldfeld dubbed "The Case of the Missing Money."2

1. See, for example, W. J. Baumol and A. S. Blinder (1999), Economics: Principles and Policy, 8th ed., Harcourt, pp. 590-591.

2. S. M. Goldfeld (1976), The Case of the Missing Money, Brookings Papers on Economic Activity 3:683-730. 
I do not wish to dispute the claim that a go-stop cycle occurred in the United States in 1972-1973. It did. But it seems a grave omission to forget the role of fiscal policy. This was the infamous period in which President Nixon opened the federal coffers to assist his 1972 reelection campaign, and then shut them abruptly in 1973. Years ago, Goldfeld and I constructed econometric-model-based measures of fiscal policy which show a titanic runup in fiscal stimulus from 1969 to a peak in 1971 and then an abrupt plunge to fiscal restraint in $1973 .{ }^{3}$ Yes, it was an aggregate-demand story; but money growth was not the only actor.

3. THE BURST OF WORLD MONEY GROWTH WAS LARGELY DUE TO THE BREAKDOWN OF THE BRETTON WOODS CONSTRAINTS ON MONEY CREATION.

I have no quarrel with highlighting the end of the Bretton Woods system as an explanation for the high money growth rates that followed, not only in the United States but in other countries. But think about the timing for a minute. The old system of fixed exchange rates died not all at once, but rather in stages between August 1971 and early 1973. That seems a bit early to account for rapid money growth in 1971 and 1972, followed by stagflation starting in late 1973. The Nixon reelection campaign-to which his friend Arthur Burns contributed from the Fed -is a more convincing explanation (or at least a partner in crime) for the United States.

4. THE SUPPLY-SHOCK THEORY OF STAGFLATION GIVES NO REASON TO THINK THAT INFLATION MEASURED BY THE GDP DEFLATOR SHOULD RISE.

Barksy and Kilian do shoot at least one hole in the supply-shock theory: It gives no reason to think the GDP deflator-as opposed to some index of consumer prices-should rise more rapidly after an oil shock. Empirically, of course, it did. This is a legitimate criticism of the conventional wisdom - which does not, of course, apply to analyses that focus on consumer-price inflation. ${ }^{4}$

Their point is really much simpler than the way they make it in the paper. Just remember that $Y=C+I+G+X-I M$ (another thing we teach our Economics 101 students), and you will notice that $I M$ enters with a minus sign. In the simple, limiting case that all imported oil is consumed and no real quantities are affected by an oil shock, nominal $C$ and nominal $I M$ would rise by identical amounts, leaving nominal GDP and all real magnitudes unchanged. Thus the GDP deflator would be unchanged.

3. A. S. Blinder and S. M. Goldfeld (1976), New measures of fiscal and monetary policy, 1958-1973, American Economic Review 66(December):780-796.

4. This caused me to check my own past work. Fortunately, it was all about consumer-price inflation. 
This, of course, is a rather unrealistic account of the way our economy reacts to an oil shock. But it does point out that we need a more complicated theory-involving, say, markups and wage-price interactions-to explain why an oil shock boosts the GDP deflator. Having said that, if we resist the conclusion that oil shocks are inherently stagflationary, we have quite a few coincidences to explain - as is clear, e.g., from the work of Jim Hamilton (cited in the paper) or Carruth, Hooker, and Oswald (1998). ${ }^{5}$

5. THE FACT THAT OIL PRICES ROSE FIRST AND STAGFLATION FOLLOWED LATER IS LARGELY EXPLAINED BY REVERSE CAUSATION: IT WAS MONETARY-INDUCED BOOMS THAT PUSHED OIL PRICES UP.

Thus do Barsky and Kilian elide the aforementioned coincidences. If I may paraphrase Shakespeare, methinks the gentlemen doth protest too much on this point.

The simple conventional wisdom holds that movements in the price of oil (which are purely exogenous) drive the economy-or, in a variant, that oil prices drive monetary policy, which in turn drives the economy. ${ }^{6}$ The Barsky-Kilian model, by contrast, holds that monetary policy drives the economy, which in turn drives the (now purely endogenous) price of oil.

In fact, reasonable people do not have to choose either of these two extremes. Two-way causation is fine-and, indeed, I think that's where Barsky and Kilian actually come out in the end. On the "oil prices are endogenous" side, there is surely truth to the notion that strong worldwide macroeconomic conditions made it easier for the OPEC cartel to work. [But didn't Rotemberg and Saloner (1986) argue that cartels break up in booms?7] But on the "oil prices are exogenous" side, I think it is a mistake to argue that money growth caused the Yom Kippur War or the fall of the Shah. Indeed, don't events like those give econometricians their best shot at cutting the Gordian knot of simultaneity?

\section{Discussion}

Robert Barsky explained that the main aim of the paper was to cast doubt on the received wisdom that stagflation in the 1970s was a result of an aggregate supply shift alone. In response to Olivier Blanchard's

5. A. Carruth, M. Hooker, and A. Oswald (1998), Input prices and unemployment equilibria: Theory and evidence for the United States, Review of Economics and Statistics LXXX, pp. 621-628.

6. See Bernanke, Gertler, and Watson (1997).

7. I realize that other theorists have argued that strong market conditions help cartels hold together. That's one of the nice features of economic theory. 
discussion, he raised the possibility that, with sufficiently responsive expectations on the part of the "awake" firms, the model in the paper might generate expected inflation greater than lagged inflation. On cartels, he said that the links between interest rates, output, and cartel power could go in both directions. In particular, when interest rates are low and output is high, the incentives to cheat might be less. Barsky responded to Alan Blinder's discussion by saying that monetary overshooting could lead to a stagflation in the model. This result depended on the amount of "sleepiness" in firms and the endogeneity of monetary policy. He stressed the similarity between their paper and Bernanke, Gertler, and Watson (1997), the main difference being that their paper argued that the Fed was responding to commodity price inflation alone, rather than to inflation in both commodity and oil prices as in BGW. Barsky agreed with Blinder that Arthur Burns might have loosened money supply to help Nixon's re-election, but he noted that commodity price inflation gave Burns the excuse he needed.

Mark Gertler suggested that, because of the regulation of depository institutions in the 1970s, increases in nominal interest rates could have had an effect on economic activity even without increases in real rates. For evidence on this point, he suggested that the authors look at what happened to housing in 1973. He agreed with Blanchard that more than a purely monetary story was necessary to explain the combination of low growth and high inflation of the early 1970s. Gertler noted the potential role of the productivity slowdown in 1972 and the resulting decline in growth; it could be argued that the Fed, failing to understand what was happening, eased policy, leading to high inflation. He put forward the possibility that the opposite has happened in recent years, during which productivity has surged and inflation has been low.

Michael Klein remarked that the exchange-rate channel was one way that a monetary expansion might have fed into a rise in the dollar price of oil. Charles Engel followed up on this comment by saying that, until 1990, a dollar depreciation was related to an increase in the price of oil, and vice versa. A possible explanation is that oil was priced in dollars. When the dollar fell, the oil price fell in Europe and Japan, increasing world demand and the world price of oil. This could be consistent with a money-based account if money growth caused the depreciation. The problem is that empirical studies have not found a close connection between monetary policy and exchange-rate changes in the short run.

David Romer agreed with the general point made by the authors that something more than an oil price shock was necessary to explain the 1970s. He was worried by the fact that, though an oil-price-shock story works well for the 1970s, oil prices are rarely invoked to explain the 
events of the past 20 years. Blinder responded that an oil-price story would work for the 1990 recession. Barsky and Romer disagreed, saying there was no stagflation in 1990. Greg Mankiw suggested that a beneficial oil shock helps to explain the economy's behavior in 1986. Olivier Blanchard said that no doubling of the price of oil had happened outside the 1970s. He maintained that the one thing that would be fatal to the oil story would be a doubling of the price of oil with no subsequent recession. Blinder remarked that 1997-1998 was characterized by a fall in oil prices, a boom, and low inflation.

Ben Bernanke noted that in the VAR literature that tries to look at the effect of oil prices on the real economy, it is hard to find a reliable statistical link between indicators of oil price shocks and subsequent output movements. But there would be some inflationary effect that leads to a policy response. Tom Sargent took up the point, saying that in a model with vintages of capital, it is difficult to find large real effects of oil prices.

David Laibson pointed out that in an $[S, s]$ model of capital formation, the effects of oil prices would be nonlinear. Dramatic price shocks in either direction could depress output through scrapping of capital. This nonlinearity could explain why the increases in oil prices of the 1970s depressed activity, while falling prices in the 1980s had ambiguous effects.

Mankiw remarked that the issue of modeling sleepy firms was an important one, as the dynamics of the model are sensitive to how sleepiness is modeled. He said that while economists have a good idea of how to model awake firms, they did not yet have good models of sleepiness.

In response to the general discussion, Lutz Kilian reiterated the key point that the prices of other commodities rose before the price of oil rose in 1973. Oil prices were different in that they remained high while other commodity prices fell. He suggested that the success of the cartel could explain why oil prices remained high. Kilian questioned the link between events such as the Yom Kippur War and the fall of the Shah of Iran on the one hand, and oil prices rises on the other, on the grounds that the timing was not right. He emphasized that embargoes could be endogenous. Barsky agreed, noting that disruptions in the Middle East don't always raise the price of oil. Rather, embargoes are imposed when it is profitable for oil producers to do so. 
